\title{
Algılanan Liderlik Stilinin İş Yaşam Kalitesi Üzerine Etkisi: X ve Y Kuşakları Arası Karşılaştırma ${ }^{1}$
}

\author{
The Effects Of Perceived Leadership Style On The Quality Of Work Life: \\ A Comparison Between Generation X And Generation Y \\ Zeynep HATIPOĞLU ${ }^{2}$ \\ Ali Akın ZENGíN ${ }^{3}$
}

\begin{abstract}
ÖZET
Araştırmada örneklem olarak Ankara, İstanbul ve İzmir illerinde her türlü kamu kurum ve kuruluşları ile özel sektörde görev yapan, 1980 öncesi ve sonrası doğmuş 447 aktif çalışan kullanılmıştır. Araştırmada "Çok Faktörlü Liderlik Anketi" (Multifactor Leadership Questionaire) ile McDonald tarafından geliştirilen "İş Yaşam Kalitesi Ölçeğì" kullanılmıştır. Elde edilen veriler SPSS programı ile çözümlenmiştir. Demografik değişkenler ile algılanan liderlik ve iş yaşam kalitesi arasındaki farkın anlamlı olup olmadığı, yine yapılan analizlerle ölçülmeye çalışılmışır. Yapılan analizlerin sonucunda; X ve Y kuşağı olmak üzere iki farklı kuşağa mensup çalışanların demografik değişkenlere ilişkin karşılaştırmalarına bakılmıştır. Tek yönlü ANOVA sonucunda cinsiyet, medeni durum ile dönüşümcü liderlik stili, sürdürümcü liderlik stili, serbestlik tanıyan liderlik stili ve iş yaşam kalitesi arasında anlamlı bir farklılık saptanmamıştır. Eğitim düzeyine bakıldığında dönüşümcü liderlik stili, sürdürümcü liderlik stili ve iş yaşam kalitesi arasında anlamlı bir farklılık tespit edilmiş; ancak serbestlik tanıyan liderlik stili ile eğitim arasında anlamlı bir farklılık olmadığı görülmüştür. Tüm değişkenlerde anlamlı bir farklılık varken, serbestlik tanıyan liderlik stili açısından farklılığın olmadığı durum, mesleğin algılanan liderlik stili ve iş yaşam kalitesi üzerindeki etkisinde de geçerlidir. Verilere mesleki kıdem yönünden bakıldığında ise dönüşümcü liderlik stili, serbestlik tanıyan liderlik stili ve iş yaşam kalitesi açısından anlamlı farklılık görülmezken, sürdürümcü liderlik stili arasında bir farklılık saptanmıştır. Kuşakların birbirleri ile ilişkilerinin düzeyini belirlemek için yapılan Pearson Korelasyon Analizi sonucu X kuşağında dönüşümcü liderlik stili ile iş yaşam kalitesi arasında anlamlı ve orta düzeyde, sürdürümcü liderlik stili ile iş yaşam kalitesi arasında anlamlı ve orta düzeyde, serbestlik tanıyan liderlik stili ile iş yaşam kalitesi arasında zayıf fakat anlamlı ilişki vardır. Y kuşağında ise dönüşümcü liderlik stili ile iş yaşam kalitesi arasında anlamlı ve orta düzeyde, sürdürümcü liderlik stili ile iş yaşam kalitesi arasında anlamlı ve orta düzeyde, serbestlik tanıyan liderlik stili ile iş yaşam kalitesi arasında zayıf fakat anlamlı ilişki olduğu saptanmıştır.
\end{abstract}

Anahtar kelimeler: Algılanan liderlik, İş yaşam kalitesi X kuşağı, Y kuşağı

JEL Sınıflandırması: J49,J29,J59

\begin{abstract}
Our study is the result of the questionnaires conducted with 447 employees who are born before and after 1980 and are actively engaged in employment in a wide range of businessess in Ankara, İstanbul and İzmir. The employees who have been took part in the questionnaires scales on "The Perceived Leadership" and "The Quality of Work Life". While doing the questionnaire, a particular attention has been paid to select the employees from diverse demographic and economic backgrounds. In the study, Multifactor Leadership Questionaire and Quality of Work Life Scale, developed by McDonald, have been used. 7 Quality of Work Life variables which were deployed were job stress, salary and benefits, job satisfaction, encouragement level, the use of skills and autonomy, the relations with collegagues, responsibility and action, communication, decision-making and job security. The data collected from the questionannaires have been analyzed through the SPSS program. In addition, the differences between demographic variables along with perceived leadership and the work life quality have been particulary controlled in order to avoid any error. As the result, a comparison has been made to analyze the differences between generations $\mathrm{X}$ and $\mathrm{Y}$ based on demographic variables. As the result of one - way ANOVA analysis, a significant distinction is not detected between sex, martial status and "transformative leadership style", "sustainable leadership style", "laissez-faire leadership style", and the quality of work life. However, when we have taken into account the educational level of the participants, a significant distinction is detected between education and "transformative leadership style", "sustainable leadership style" along with the quality of work life even though this sort of distinction has not turned to be the case for "laissez-faire leadership style". Meaningful there have been meaningul differences among all variables, no serious distinction has been identified between "perceived leadership" and the quality of work life concerning the "laissez-faire leadership style". A particular difference concerning "sustainable leadership style" is distinguished
\end{abstract}

\footnotetext{
${ }^{1}$ Bu çalışma 2018 yılında NIŞANTAŞI ÜNIVERSITTESİ, Sosyal Bilimler Enstitüsü, İşletme Yönetimi Bölümü’ne yüksek lisans tezi olarak sunulan ve kabul edilen tez çalışmasından türetilmiştir.

${ }^{2}$ Dr.Öğr.Üys., Nişantaşı Üniversitesi, zynhatipoglu@gmail.com

${ }^{3}$ Ali Akın Zengin, Nişantaşı Üniversitesi, aakinzengin@gmail.com
} 
while this difference has not been applicable for "transformative leadership style", "laissez-faire leadership style" and the quality of work life. As the result of Pearson's Correlation Analysis, which is used to determine the level of relations between generations, it has been emphasized that concerning generation $\mathrm{X}$ there is a meaningful, medium-level relation between "transformative leadership style" and the sense of the quality of work life. While the relation between "sustainable leadership style" and the sense of quality of work life is also determined to be a meaningful, medium-level one, the relation between "laissez-faire leadership style" and the sense of the quality of work life is estimated to be a significant one, yet weakened. In case of the generation $\mathrm{Y}$, it is detected that there is a meaningful, medium-level relation between "transformative leadership style" and the sense of the quality of work life. While the relation between "sustainable leadership style" and the sense of the quality of work life is also determined to be a meaningful, medium-level one, the relation between "laissez-faire leadership style" and the sense of the quality of work life is estimated to be a significant yet weakened one.

Key Words: “The Perceived Leadership”,the quality of work life, Generation X,Generation Y.

JEL Classification: J49,J29,J59

\section{Giriş}

Nüfusun artışı ve teknolojinin gelişimi ile birlikte, toplumsal gereksinimlere cevap verme niyetiyle kurulan örgütlerin ve işletmelerin sayısı artmaktadır. Her şeyin kolay ulaşılabilir olduğu, istenen mal ve emele rahatça ulaşılabilen piyasalarda rekabet yaşanmamaktadır; ancak artan işletme sayısı ve nüfusla birlikte rekabet, işletmeler bazında kaçınılmaz bir dinamik olmakta, rekabet ortamı keskinleşmektedir.

Her örgüt temel hedeflerine ulaşabilmesi ve bu süreçteki işlerin idaresi için bir lidere veya yöneticiye ihtiyaç duyar ve örgütün temel bileşenlerinden olan yönetici veya liderde bulunması gereken belli başlı nitelikler vardır: Öncelikle yönetim bir işin sevk ve idaresi iken, yönetici işletmenin ekonomik gidişatından etkilenmeksizin, yönetim sorumluluğunu yüklenen kişidir (Onal, 1993). Liderlik ise statüye bağlı olmayan ikna eden, harekete geçiren, öncülük eden gibi kişisel bir süreç iken; lider ise bu süreçte etkin eylemleri gerçekleştiren yeterliliğe sahip kişi olarak tanımlanmaktadır (Özcan Y.,2006). Ayrıca lider tanımlarına bakıldığında ise birçok yönetici tanımında olduğu gibi, belirli amaçları gerçekleştirmek üzere bir kimsenin ya da bir grubun faaliyetlerini yönlendirebilme ve etkileyebilme becerisi olduğu ortaya çıkmaktadır.

Araştırmamızda X ve Y kuşağı yaş aralığında olan birçok çalışan üzerinde bilimsel geçerliliği kanıtlanmış anketler uygulanmıştır. Yapılan açıklamalardan ve kavram telaffuzlarından yola çıkarak bu anketlerde, çalışanların algıladıkları liderlik stilleri ile iş yaşam kaliteleri arasındaki ilişki kuşaklar bazında sorgulanmış ve anlamlı bir ilişkinin bulunup bulunmadığı açığa çıkarılmaya çalışılmıştır. Çalışanların işi algılayış biçimleri, iş yaşam kalitesi kavramının çalışma yaşamındaki önemi, iş yaşamına etki eden faktörler, iş yaşam kalitesinin boyutları, kuramları ve sonuçları, algılanan liderlik stilinin boyutları ile bir arada ele alınarak ifade edilmiştir. Ankete katılan kişilerin cinsiyeti, yaşı, medeni durumu, çalışma alanı, öğrenim düzeyi ve mesleki kıdemine göre değerlendirme yapılmıştır.

Aktif olarak çalışma hayatının içinde yer alan farklı kuşaklara ait çalışanların dönüşümcü, sürdürümcü ve serbestlik tanıyan liderlik stili algıları kapsamında iş yaşam kaliteleri değerlendirilmiştir. Kuşaklar bazındaki farklılıkların ortaya konulduğu bu araştırmada, liderlerin ve yöneticilerin kendi liderlik stilleri hakkında bilgi edinmelerini ve çalışanların ise yönetme biçimlerini nasıl algıladıklarına açıklık getirilmeye çalışılmıştır. Hangi liderlik stili ile çalışanların iş yaşam kaliteleri arasında anlamlı ve pozitif bir ilişkinin olduğunun ortaya çıkarılması, yöneticilere yol göstermesi açısından önem arz etmektedir. Söz konusu çalışmanın çalışanlar açısından ise bilgilendirici olacağı düşünülmektedir.

\section{Liderlik}

Liderlik anlam olarak İngilizce bir sözcük olan “leader” kelimesinden gelmektedir. Sözlük anlamı önder, baş, rehber, öncü, yönlendirici vb. kavramlarla ifade edilmektedir. Kelimenin asıl kökü olan "lead” ise; öncülük yapmak, yol göstermek, başını çekmek ve yönlendirmek anlamındadır.

Yönetim alanında araştırmalar yapan bilim adamlarının en çok araştırma yaptığı konular arasında sayılabilecek olan liderlik, binlerce deneysel çalışmanın ve tanımlamanın öznesi olmuştur. Çelik, (2013)'e göre bunlardan bazıları şu şekilde sınıflandırılabilir: 
- $\quad$ Liderlik, grup hedeflerine ulaşmak adına grup çalışmasına etkide bulunmaktır. (Bass,1985).

- Liderlik, çalışanların eylemlerine etkide bulunarak onları istediği şekilde yönetebilme becerisidir (Bennis\&Nanus, 1985, s.56).

- $\quad$ Liderlik, lider ve grup üyeleri arasında karşılıklı bir etkileşim sürecidir (Graen, 1976, s.1 16).

- $\quad$ Liderlik, çalışanlar üzerinde ciddi bir etki yaratmaktır (Argyris, 1976, s.227).

- $\quad$ Liderlik, karşısındakini etkileyebilme potansiyelini ifade eden bir ayrıcalıktır (Etzioni, 1964).

- $\quad$ Liderlik, çalışanların uygulamaya dönüşecek hareketlerini etkileyebilecek bir kuvvettir (Zaleznik, 1977, s.267).

Yöneticinin aksine liderin hareket kabiliyeti tanımlanmış bir yetkiden doğmaz. Yetkisi olduğu halde ardından kimsenin gitmediği yöneticiler olduğu gibi tanımlanmış bir görevi olmadığı halde birçok insanı arkasından getirebilme yeteneğine sahip liderler olduğu bilinmektedir (Mutlu, 1995). Bu sebepten lider çalışanların mevcut ihtiyaçlarına cevap verebilen ve onları ortak hedefe yönlendirebilen kişiler olacaktır (Eren, Örgütsel Davranış ve Yönetim Psikolojisi, 2005).

Günümüzde liderlerin temel rolü: bireysel olarak, grup olarak ve örgütsel olarak çalışanların öğrenmelerini kolaylaştıran ve buna yönelik motivasyonlarını arttıran; onlara yeni bir vizyon sağlayarak doğru bilgiyi aramalarına olanak sağlayan bir ortam yaratmaktır (Eğriboyun, 2015, s. 35). Yani liderlik etmeyi kavramsal açıdan toplumu oluşturan bireyleri belirli amaçlar doğrultusunda bir araya toplayarak onları belirlenen hedeflere yöneltmek olarak tanımlayabiliriz. İşletmeler açısından ise çalışanları işletme amaçları çatısında toplayarak, hedefi gerçekleştirmek için onların verimli çalışabilmesini sağlamaktır diyebiliriz. (Güney, 2009, s. 372). Araştırmada çağdaş diğer adı ile modern liderlik tarzları başlığı kabul edilen sürdürümcü liderlik, dönüşümcü liderlik ve geleneksel liderlik tarzları başlığı altında kabul edilen serbestlik tanıyan liderlik yaklaşımları incelenmiştir.

\subsection{Transaksiyonel (Sürdürümcü) Liderlik}

1970’lerin sonlarına doğru J. M. Burns tarafından öne sürülen, daha sonra B. M. Bass’in başını çektiği araştırmacılar tarafından geliştirilen yaklaşımın temel aldığı nokta; bir işi gerçekleştirmek üzere bir gruba liderlik yapan kişi ve grup üyeleri arasındaki işten kaynaklı kurulan ilişki ve liderin göstereceği davranış tarzlarıdır (Koçel, 2015, s. 695). Genellikle gelenekçi bir yapıya sahip olan sürdürümcü olarak adlandırılan liderler, geçmişteki olumlu gelenekleri sürdürerek bunların ileriye taşınmasına yardımcı olurlar (Tengilimoğlu, 2005, s. 6).

$\mathrm{Bu}$ modelde astlar, liderin isteklerini yerine getirmeleri durumunda pozitif bir geribildirim ve destek ile ödüllendirilirken; liderin istekleri yerine getirilemez ve istenen amaca ulaşılamazsa lider yaptırımları ile karşı karşıya kalacaklardır (Akdemir, 1998, s. 58). Transaksiyonel liderlikte rutin olarak gerçekleştirilen işlerde en yüksek verim sağlanması amaçlanır (Bakan \& Büyükbeşe, 2010, s. 75). Lakomski’ye göre transaksiyonel liderlik ile ilgili yapılan teorik çalışmalar neticesinde bu liderlik tipinin üç temel özelliği olduğu belirtilmiştir (Akt. Sabuncuoğlu \& Tüz, 2013, s. 223-224):

- $\quad$ Liderin önceden belirlenen hedeflere ulaşmaları durumunda çalışanlarına vereceği ödülü nitelendiren "şarta bağlı ödüll"

- $\quad$ Örgütte bir problem ya da hata meydana geldiğinde liderin bu problem ya da hatayı çözmek için harekete geçmesini ifade eden "istisnalarla yönetim (aktif)"

- Çalışanların özgür bırakıldığı ve bu yönüyle serbest bırakıcı liderlik modelini de anımsatan "istisnalarla yönetim (pasif)"

Yukarıda belirtilen son özellikte bir problemle karşılaşan lider olaylara hemen müdahale etmez ve çalışanların çözüm bulmasını tercih eder. Yani diğer bir anlamıyla problemler ciddileşinceye kadar lider müdahale etmez. Sürdürümcü liderler mevcut yapıyı korumak için çalışanları güdüleyen, doyumsal ihtiyaçlarına cevap veren, çalışanlara liderlik etmekten çok sadece belirli ölçüde yönetimsel davranışlar sergileyen, örgütte sorun çıkmaması adına gerekli tedbirleri alan kişilerdir (Akan \& Yalçın, 2015, s. 126). Kontrole büyük önem veren sürdürümcü liderler, astlarına karşı bulundukları konumun onlara sağladığı yasal, zorlayıcı ve ödül güçlerini kullanırken, onların psikolojik durumlarını önemsemeyerek programlanmış birer robot gibi davranmalarını isterler (Güney, 2009, s. 417).

\subsection{Transformasyonel (Dönüşümcü) Liderlik}

Dönüşümcü liderlik karizmatik liderlikte olduğu gibi astların daha yüksek seviyede başarı sağlayabilmesi için motive edilmesi gerektiğini savunan, yüzünü geleceğe, yeniliğe ve değişime dönmüş, vizyon sahibi olarak bu vizyonu 
astlarına kabul ettirmiş bir liderlik modelidir (Çelik \& Eryılmaz, 2006). Dönüşümcü liderler; örgütte çalışan bireylerin enerjilerini, beklentilerini, taleplerini ve hedeflerini grubun amaçları doğrultusunda şekillendirerek ortak bir amaç, inanç ve eşgüdüm oluşturarak grubun yaşam kalitesini arttıran, bu sayede amaçların gerçekleşmesi adına aslında bir sinerji ortaya çıkarmayı başaranlardır (Akan \& Yalçın, 2015).

Dönüşümcü diğer adıyla transformasyonel liderler sadece araştıran ve sorgulayan kişiler değil; geleneksel bürokraside girişimciliğe ve kendini geliştirmeye uygun ortam yaratan, yüksek enerjiye sahip, bireyin grubun ve toplumun ortak menfaatleri doğrultusunda hareket etmesini sağlayan, davranışları ile insanlara belli düşünceleri aşılayan kişilerdir (Çelik V. , 2013, s. 151).

Judge ve Piccolo (2004), dönüşümcü liderin dört tip davranış biçiminin olduğunu belirtir. Bunları biraz daha ayrıntılı bir biçimde ifade ederek şu hususları belirtmişlerdir:

- $\quad$ Lider bir işi yaparken belirlemiş olduğu yüksek motivasyon ve ahlaki değerler ile çalışanların saygısını kazanarak kendisine olan bağlılıklarını yükseltir,

- $\quad$ Liderin ortaya koyduğu vizyon, çalışanlarda lidere karşı güveni arttırarak onu duygusal olarak takip etme ihtiyacı hissettirir,

- $\quad$ Lider eski varsayımları sorgulayarak yeni bakış açıları getirir ve çalışanları da bu yönde hareket etmesi için güdüler,

- $\quad$ Lider grubunda bulunana her bir çalışanı ile bireysel olarak ilgilenir, onların bireysel gelişimi sağlayacak bir koç gibi davranır.

Dönüşümcü liderlik üzerinde ayrıntılı araştırmalar yapan Bass, liderin astları üzerindeki yeteneklerinin gün yüzüne çıkarılması, kendilerine olan güvenlerinin arttırılması, motive edilmeleri, değer yargılarının ve inançlarının değiştirilmesi gibi etkilerine karşılık, astların liderin hedeflerini gerçek kılmak gibi pozitif bir tepkiyle karşılık vererek iki taraflı güdülenmenin gerçekleşmiş olduğunu ifade etmektedir (Akt. Çelik \& Sünbül, 2008). Dönüşümcü liderlik çalışanlara vizyon kazandırarak, onları yeniliğin ve değişimin gerekliliğine inandırmak, çalışanların işe karşı olan arzu ve isteklerini kamçılaması, orijinal fikir ve çalışmaların ortaya çıkarılmasını sağlaması yönünden faydalıdır (Eren, Örgütsel Davranış ve Yönetim Psikolojisi, 2005, s. 461).

\subsection{Serbestlik Tanıyan Liderlik}

Tam serbesti tanıyan liderler yönetim yetkisini aktif olarak fazla kullanmayan, astlarını yönlendirmeye çok az başvuran ve sorumluluk almaktan kaçınan kişiler olarak tanımlanırlar. Bu liderlik tipinde astlara örgütün amaçları sunularak kişisel becerileri ile bu amaca varmaları hususunda tam olarak serbesti sağlanır.

Lider grup üyelerinin gelişimi için herhangi bir çaba harcamadığından astlar kendi kendilerini eğiterek motive etmektedir. Tam bir otokontrol anlayışının hâkim olduğu liderlik tarzında lider görüşlerini açıklamaktan kaçınmakta, sadece bir konuda fikri sorulduğunda görüş bildirmektedir (Sabuncuoğlu \& Tüz, 2013, s. 215). Karip'e göre; bu gibi liderle grup üyeleri arasındaki iletişimin sınırlı olduğu durumlar ve idare etme gücüne duyulan gereksinim çok az olması liderlik etme özellikleri tam olmayan idarecilerde çokça görülmektedir. (Canbolat, 2016, s. 31). Bu liderlik tipi, liderin hareket alanını yok etmekte, grubu beraberce belirlenmiş hedeflere yöneltmekten yoksun bırakmakta ve bireysel başarı dışında grup başarısının önemli ölçüde azalmasına sebep olmaktadır. Diğer yandan ise her üyenin bireysel yeteneklerini ön plana çıkarması, üyelerin özgürce kararlar alabilmesine imkân vermesi ve astların gerekli gördüklerinde yeni fikirleri test edebilmesi için gruplar kurmasına imkân sağlaması bu liderlik tipinin olumlu yönleri arasında değerlendirilebilir. (Sabuncuoğlu \& Tüz, 2013, s. 215)

\section{4.İş Yaşam Kalitesi}

Bir işletmede insan, üretimin temel bileşenlerinden biridir. Çalışma alanı ise; insan hayatında önemli bir yer tutan sadece bir kazanç alanı değil, aynı zamanda sosyal bir uğraşı alanıdır (Tuncer \& Yeşiltaş, 2013, s. 60). Kalite ise genellikle bir organizasyon, olay, ürün, kişi, hizmet veya faaliyetin benzerinden farklılığını ifade eden, "amaca uygunluk", "tüketicinin tatmini”, "isteklere uygunluk" ve en genel tanımıyla "şartlara uygunluk" olarak ifade edilen bir kavramdır (Boran, 2008).

Özellikle 1930’lu yıllardan sonra “işyerlerinde çalışanlar” araştırmacılar tarafından ilgi çekici bulunup araştırılmaya başlanmıştır. Çalışanların iş yaşam kalitelerindeki doyum düzeylerinin performans ve toplam verimliliklerine ne ölçüde etki ettiğine dair çalışmalar yapılmaya başlanmıştır (Özcan E. , 2011). 1970'li yıllara kadar iş yaşam kalitesini 
kapsayan birçok konu farklı adlarla gerek akademik olarak gerekse sivil toplum kuruluşları tarafından araştırma konusu olmuştur (Erdem M. , 2010). Mesleki ve toplumsal alanda küresel düzeyde yaşanan birçok değişiklik iş, işyeri, çalışanlar, iş yaşam etkileşimi ve bunun kalitesi gibi konulara olan ilgiyi artırmış, bu konuların özellikle son yirmi yıl içerisinde disiplinler arası yaklaşımlarla ele alınabilecek hale gelmesine yol açmıştır (Tütüncü, 2008, s. 178).

Modern yönetim anlayışlarının yaygınlık kazanmasıyla işletmelerde çalışanlara daha çok önem verilmeye başlanmış ve iş yaşam kalitesi işyerlerinde çalışanların motivasyonlarını arttırarak verimliliklerini üst düzeye çıkarmayı hedefleyen ve çalışanların şahsi beklentilerine önem veren bir teknik olarak görülmeye başlanmıştır (Serbest, 2000, s. 31). Bu kavram çalışma koşullarından çalışan memnuniyetine, üretimdeki verimlilik konusunda yönetimin payından toplumsal bütünlüğe kadar uzanan geniş bir kavramdır. (Aba, 2009).

İş yaşam kalitesi kavramının özgün haline bakıldığında işçi ve iş ortamı arasında varolan ilişkinin niteliği üzerine durulduğunu belirten Al-Qutop ve Harrim (2011), artık işin teknik ve ekonomik boyutunun yanında ihmal edilen insan boyutunun da vurgulanmasının gerekliliğini belirtmişlerdir (Akt. Yıldız, 2013). İş yaşam kalitesi; fazlaca insancıllaştırılmış çalışma koşulları yaratmak adına, çalışanın temel ihtiyaçlarından ziyade zihinsel, psikolojik ve sosyal gereksinimlerinin de karşılanmasını, yani iş ortamının çalışanların kişisel ihtiyaçlarına göre yeniden tasarlanmasını ifade etmektedir (Aba, 2009).

\section{Araştırma}

Araştırmanın amacı Ankara, İstanbul ve İzmir illerinde kamu ve özel sektörde çalışanların iş yaşam kaliteleri ile algıladıkları liderlik tarzları arasındaki ilişkilerin düzeyinin belirlenmesi ve iş yaşam kalitesinin algılanan liderlik tarzı üzerindeki etkilerinin araştırılmasıdır.

İş yaşam kalitesi ve algılanan liderlik arasındaki ilişkiyi irdeleyen çalışmalar arasında her ne kadar eski tarihliler olsa da, bu alandaki çalışmalar yeni yeni yaygınlık kazanmaya başlamıştır. İş bu çalışmada da yerli ve yabancı alanda birçok kaynak taraması yapılmış ve iş yaşam kalitesi ile liderlik alanında bilimsel çalışmalara yer verilerek geniş bir kavramsal çerçeve oluşturulmuştur.

Çalışmada dönüşümcü liderlik stili, sürdürümcü liderlik stili, serbestlik tanıyan liderlik stili olarak belirtilen bileşenlerin 1980 öncesi doğumlu olan X kuşağı ve 1980 sonrasında dünyaya gelenlerin oluşturduğu Y kuşağının işe yönelik algılarının iş yaşam kalitesi üzerindeki etkisi incelenmiştir. Çalışmanın bağımsız değişkenlerini cinsiyet, medeni durum, eğitim düzeyi, kamu personeli veya özel sektörde çalışma durumu ve mesleki kıdemi oluşturmaktadır. Kuşaklar açısından üç liderlik bileşenini dikkate alarak iş yaşam kalitesini ne düzeyde etkilediği araştırılmış ve kuşaklar arasında farklılık olup olmadığı belirlenmiştir.

Temel olarak iş yaşam kalitesinin ve algılanan liderlikten ne ölçüde etkilendiğinin saptanmaya çalışıldığ araştırmada çok çeşitli boyutların çalışanların algıladıkları liderlik üzerindeki gücü ve birçok farklı özellik ile liderlik stilinin çalışanların yaşam kalitesini ne ölçüde etkilediği ortaya konulacaktır.

\subsection{Veri Toplama Aracının Güvenilirlik ve Geçerlilik Analizleri}

Genel güvenirlik ve alt boyutların güvenirliği için Cronbach’s Alpha katsayısı hesaplanmıştır. Güvenirlilik; bir ölçme aracında bütün soruların birbirleriyle tutarlılığını, ele alınan oluşumu ölçmede türdeşliğini, yeterliliğini ortaya koyan bir kavramdır. Testlerin güvenirliliğini değerlendirmek amacıyla geliştirilmiş yöntemlere güvenirlilik analizi ve bu testte yer alan soruların irdelenmesine ise soru analizi denilmektedir. Cronbach's Alfa katsayısının bulunabileceği aralıklar ve buna bağlı olarak da ölçeğin güvenirlik durumu aşağıda verilmiştir.

$0,00 \leq \alpha<0,40$ ise ölçek güvenilir değildir

$0,40 \leq \alpha<0,60$ ise ölçek düşük güvenilirliktedir

$0,60 \leq \alpha<0,80$ ise ölçek oldukça güvenilirdir

$0,80 \leq \alpha<1,00$ ise ölçek yüksek derecede güvenilir bir ölçektir

Sonuçlar yüzde 95 güven düzeyinde, 0,05 anlamlılık ile çift yönlü olarak incelenip değerlendirilmiştir.

Tablo 1 -Cronbach's Alpha değeri 


\begin{tabular}{|l|l|l|}
\hline & $\begin{array}{l}\text { Cronbach's Alpha } \\
\text { Değeri }\end{array}$ & N \\
\hline Çalı̧smanın geneli & .869 & 76 \\
\hline Algılanan Liderlik Stili & .866 & 36 \\
\hline İş Yaşam Kalitesi & .703 & 40 \\
\hline
\end{tabular}

Cronbach's Alpha değerleri oldukça güvenilir çıkmıştır. Bu değerlerin güvenirliliklerini daha iyi göstermek ve ölçeğin geçerliliğini sınamak amacıyla faktör analizi yapılarak KMO değeri elde edilmiştir.

Faktör analizi; çok sayıdaki değişkeni, belirli sayıda gruplara ayırarak, her bir grubun içindeki değişkenler arasındaki ilişkiyi maksimum, gruplar arasındaki ilişkiyi ise minimum yaparak grupları yeni değişkenlere dönüştüren bir analiz türüdür. Türetilen bu yeni değişsenlere faktör adı verilir. Faktör analizi, çok sayıdaki değişken arasındaki ilişkilere dayanarak, birbirinden bağımsız ve daha az sayıda daha anlamlı ve özet bir biçimde yeni değiş̧kenler bulunmasını sağlar(Karagöz, 2014).

Kaiser-Meyer-Olkin (KMO) testi analizde örneklem yeterliliğini ölçer ve örneklem büyüklüğü ile ilgilenir. Bunun için gözlenen korelasyon katsayılarının büyüklüğü ile kısmı korelasyon katsayılarının büyüklüğünü karşılaştırır. $\mathrm{Bu}$ testin değeri küçük çıkarsa, çift olarak değişkenler arasındaki korelasyon ilişkisinin, diğer değişkenlerce açıklanamayacağını gösterir. Bu durumda faktör analizine devam etmek doğru olmaz (Nakip 2003, 408-409). KMO testinde bulunan değer 0,50 'nin altında ise kabul edilemez, 0,50 zayıf, 0,60 orta, 0,70 iyi, 0,80 çok iyi 0,90 mükemmeldir. (Sharma 1996: 116, Tavşancıl 2002:50, Altunşık vd.2005: 217)

Çalışma sonuçlarına ilişsin KMO ve Bartlett's test sonuçlarına Tablo 2'de yer verilmiştir.

Tablo 2 - KMO ve Bartlett's Test Sonuçları

\begin{tabular}{|l|l|l|}
\hline Kaiser-Meyer-Olkin Örneklem Değeri & & .522 \\
\hline \multirow{2}{*}{ Bartlett's Testi } & Yaklaşık Ki-Kare & 478.016 \\
\cline { 2 - 3 } & & 6 \\
\cline { 2 - 3 } & Df & .000 \\
\cline { 2 - 3 } & Sig. & \\
\hline
\end{tabular}

Bartlett Testi ölçü serilerinin dağılımında anormallikler olup olmadığını kontrol eder. Bartlett testinin anlamlı çıkması verilerin faktör analizi için uygun olup olmadığını göstermektedir. Bu nedenle elde edilen değerler, örneklem büyüklüğünün yeterli ve elde edilen verilerin faktör analizi için uygun olup olmadığının bir göstergesi olarak kabul edilmiştir. Bu analizde örneklem genişliğinin yeterli olduğu görülmektedir ve temel bileşenler analizine devam edilebilir.

\subsection{Araştırma Metodolojisi}

Araştırmada değişkenleri ifade etmek için kullanılan kavramları test edebilmek amacıyla literatürde geçerli ve güvenli kabul edilen ölçekler taranarak çalışmamıza uygun olan "Çok Faktörlü Liderlik Ölçeği" ile "İ̧̧ Yaşam Kalitesi Ölçeği”" kullanılmıştır. Bu araştırmanın evrenini Ankara, İstanbul ve İzmir illerinde kamu ve özel sektör bazında birçok ilde görev yapan 447 aktif çalışan kişi oluşturmaktadır. Araştırma anketi toplamda 600 kişiye gönderilmiş fakat bunlardan sadece 447'si hem Algılanan Liderlik Stili Ölçeği hem de İş Yaşam Kalitesi Ölçeği anketlerini eksiksiz olarak yanıtlamıştır. 
Bernard Bass tarafından ortaya çıkarılan “Çok Faktörlü Liderlik Ölçeği” ile 1978 yılında James McGregor Burns tarafından sistematize edilen "dönüşümcü liderlik" kavramı ilk kez ölçülebilir ve anlaşılabilir bir noktaya taşınmıştır. Yani bu anket yardımı ile liderin her açıdan resmini çekmek mümkün olmuştur. (Şirin \& Yetim, 2009) Ölçeğin çevirisi Akdoğan tarafından konunun uzmanı üç kişiye yaptırılmış, farklı yargılarla tartışılarak doğru verilere ulaşılmıştır (Başaran A., 2006, s. 124). Ölçekte bulunan 36 ifade ve "Hiçbir Zaman”dan, "Daima"ya kadar 5 aşamalı likert tipi değerlendirme seçenekleri bulunmaktadır. Bu 36 ifadenin ölçtüğü liderlik stilleri 3 genel faktör altında ayrıntılı 7 faktörden meydana gelmektedir.

Tablo 3- Çok Faktörlü Liderlik Ölçeği Boyutları

\begin{tabular}{|c|c|c|}
\hline \multicolumn{3}{|l|}{ DÖNÜŞÜMCÜ LİDERLİK } \\
\hline KARİZMATİK/İLHAM VERİCİ & $6,9,10,13,14,18,23,25,34,36$ & 10 \\
\hline ENTELEKTÜEL UYARIM & $2,8,30,32$ & 4 \\
\hline BİREYSEL DESTEK & $15,1929,31,35$ & 5 \\
\hline TOPLAM & \multicolumn{2}{|l|}{19} \\
\hline \multicolumn{3}{|l|}{ SÜRDÜRÜMCÜ LİDERLİK } \\
\hline ÖDÜLE BAĞLI & $1,16,11$ & 3 \\
\hline İSTİSNALARLA YÖNETİM (AKTİF) & $4,21,22,24,26,27$ & 6 \\
\hline $\begin{array}{l}\text { İSTISNALARLA YÖNETIM } \\
\text { (PASİF) }\end{array}$ & $3,12,20$ & 3 \\
\hline TOPLAM & \multicolumn{2}{|l|}{12} \\
\hline \multicolumn{3}{|l|}{ SERBESTLIKK TANIYAN LİDERLİK } \\
\hline & $5,7,17,28,33$ & 5 \\
\hline
\end{tabular}

Çalışanların iş yaşam kalitesi algılarına yönelik görüşlerini belirlemek amacıyla ise McDonald tarafından geliştirilen ve Kösterelioğlu (2011) tarafından uyarlanan “İş Yaşam Kalitesi Ölçeği” kullanılmıştır. Ölçekte iş doyumu, teşvik etme derecesi, becerilerin kullanımı ve otonomi, iş arkadaşları ile ilişkiler, iş yerinde sorumluluk ve görev alma, iletişim, karar alma ve iş güvenliği olmak üzere 7 boyut ile olumlu ve olumsuz ifadeler içeren ve 53 maddeden oluşan puanlamasında "kesinlikle katılmıyorum", "katılmıyorum", "kararsızım", "katılıyorum" ve "kesinlike katılıyorum” şeklinde görüşler bulunmaktadır (Kösterelioğlu, 2011, s. 81).

Tablo 4 - İş Yaşam Kalitesi Ölçeği Boyutları

\begin{tabular}{|l|l|l|}
\hline BOYUTLAR & $\begin{array}{l}\text { ÖZET } \\
\text { TANIMLAMA }\end{array}$ & MADDE SAYISI \\
\hline $\begin{array}{l}\text { İş doyumu, Teşvik Etme Derecesi, } \\
\text { Otonomi }\end{array}$ & İş doyumu & 12 \\
\hline İletişim, Karar Alma ve İş Güvenliği & İletişim & 10 \\
\hline Yönetici Desteği & Destek & 10 \\
\hline İş̇̇e İlgili Stres Yaşamama & Stressizlik & 8 \\
\hline Ücret ve Ek Getiriler & Ücret & 5 \\
\hline İş Arkadaşları İle İlişkiler & İlişkiler & 5 \\
\hline İş Yerinde Sorumluluk ve Görev Alma & Dâhil olma & 3 \\
\hline
\end{tabular}

\subsection{Araştırma Kısıtları}

Araştırmanın kısıt verileri Ankara, İstanbul ve İzmir illerinde her türlü kamu kurum ve kuruluşları ile özel sektörde bankacılık-finans, eğitim, gıda, kimya, perakende, elektronik, otomotiv, turizm, bilişim, madencilik, hizmet sektörü gibi birçok değişik faaliyet kolunda çalışan 1980 öncesi ve sonrası doğan 447 kişiden oluşmaktadır. Söz konusu çalışmayı cevaplandıranlar demografik ve ekonomik özellikler itibariyle yaklaşık olarak aynı gelir ve statüye sahip kişiler yerine farklı gelir ve statüye sahip kişiler arasından seçilmiştir. Anketler toplamda 20 günlük süre zarfinda tamamlanmıştır. 


\subsection{Araştırma Hipotezleri}

$\mathrm{H}_{1}$ : Dönüşümcü liderlik stili algısı ile iş yaşam kalitesi arasında anlamlı bir ilişki vardır.

$\mathrm{H}_{2}$ : Sürdürümcü liderlik stili algısı ile iş yaşam kalitesi arasında anlamlı bir ilişki vardır.

$\mathrm{H}_{3}$ : Serbestlik tanıyan liderlik stili algısı ile iş yaşam kalitesi arasında anlamlı bir ilişki vardır.

$\mathrm{H}_{4}$ : X kuşağında dönüşümcü liderlik stili algısı ile iş yaşam kalitesi arasındaki ilişki Y kuşağından farklıdır.

$\mathrm{H}_{5}$ : X kuşağında sürdürümcü liderlik stili algısı ile iş yaşam kalitesi arasındaki ilişki Y kuşağından farklıdır.

$\mathrm{H}_{6}$ : X kuşağında serbestlik tanıyan liderlik stili algısı ile iş yaşam kalitesi arasındaki ilişki Y kuşağından farklıdır.

\subsection{Araştırma Bulguları ve Değerlendirmeler}

Verilerin analizinde IBM SPSS Statistics 23.0 ve LISREL 9.2 istatistik paket programı kullanılmıştır. Hipotezlerin test edilebilmesi için öncelikle ölçeklerin güvenilirlik ve geçerlilik analizleri yapılmıştır. Normalliği test edildikten sonra frekans analizi yardımı ile güvenilirlik ve geçerliliği test edilmiş olan araştırma verilerindeki değişkenlerin sıklık dağılımları belirlenmiştir. Daha sonra ise çoklu faktör analizi ve çoklu regresyon analizi uygulanarak veriler analiz edilmiştir. Analizlerin sonuçlarına ilişskin ayrıntılı bilgi ve yorumlar aşağıda yer almaktadır.

Ankete katılan kişilerin yüzde 72.2'si (325 kişi) 1980 öncesi doğumlu ve X kuşağına mensuptur. Ankete katılan kişilerin yüzde 27,3'ü (122 kişi) ise 1980 sonrası doğumlu ve Y kuşağına mensuptur. Katılımcıların yüzde 58.8'i (\%58.8) (263 kişi) kadın, katılımcıların yüzde 41.2'si (\%41) (184 kişi) erkektir. Katılımcıların yüzde 55'i (246 kişi) evli, yüzde 45’i (201 kişi) ise bekârdır. Katılımcıların yüzde 17'si (76 kişi) lise mezunu, yüzde 15,2'si (68 kişi) önlisans mezunu, yüzde 50,8'i (227) lisans mezunu, yüzde 17'si (76 kişi) lisansüstü eğitim düzeyinde insanlardan oluşmaktadır. Katılımcıların yüzde 41.6'sı (186 kişi) kamu personeli, yüzde 58.4'ü (261 kişi) özel sektör çalışanıdır. Katılımcıların yüzde 35.5'i (157 kişi) 5 yıllık çalışan, yüzde 28,6'sı (128 kişi) 6 yıl - 10 yıl arası çalışan, yüzde 13,6'sı (61 kişi) 11 yıl - 15 yıl arası çalışan, yüzde 7.2'si (32 kişi) 16 yıl - 20 yıl arası çalışan, yüzde 7.2'si (32 kişi) 21 yıl - 25 yıl arası çalışan, yüzde 8.3'ü (37 kişi) 26 yıl ve daha fazla süredir çalışanlardan oluşmaktadır. Araştırmaya katılan Y kuşağı katılımcılarının yüzde 72.2'si (190 kişi) kadın, yüzde 73.4’i (135 kişi) erkeklerden oluşmaktadır. X kuşağı katılımcılarının ise yüzde 27.8'i (73 kişi) kadın, yüzde 26.6'sı (49 kişi) erkektir. Araştırmaya katılan Y kuşağı katılımcılarının yüzde 59.3'ü (146 kişi) evli, yüzde 89.1'i (179 kişi) bekârlardan oluşmaktadır. X kuşağı katılımcılarının ise yüzde 40.7'si (100 kişi) evli, yüzde 10.9 (22 kişi) bekârdır. Araştırmaya katılan Y kuşağı katılımcılarının yüzde 67,1'i (51 kişi) lise, yüzde 79,4'ü (54 kişi) önlisans, yüzde 71,8'i (163) lisans, yüzde 75'i (57 kişi) lisansüstü oluşmaktadır. X kuşağı katılımcılarının ise yüzde 32,9'u (25 kişi) lise, yüzde 20,6’sı (14 kişi) önlisans, yüzde 28,2'si (64 kişi) lisans, yüzde 25'i (19 kişi) lisansüstü oluşmaktadır. Araştırmaya katılan Y kuşağı katılımcılarının yüzde 60,2'si (112 kişi) kamu personeli, yüzde 81,6'sı (213 kişi) özel sektör personelinden oluşmaktadır. X kuşağı katılımcılarının ise yüzde 39,8'i (74 kişi) kamu personeli, yüzde 18,4'ü (48 kişi) özel sektördür. Y kuşağındaki katılımcıların yüzde 94,9’u (149 kişi) 0-5 yıllık çalışan, yüzde 94,5'sı (121 kişi) 6 yıl - 10 yıl arası çalışan, yüzde 72,1'sı (44 kişi) 11 yıl - 15 yıl arası çalışan, yüzde 31,3'si (10 kişi) 16 yıl - 20 yıl arası çalışan, yüzde 3,1'i (1 kişi) 21 yıl - 25 yıl arası çalışanlardan oluşmaktadır. Y kuşağında yaşları itibariyle 26 yıl ve daha fazla süredir çalışan bulunması mümkün olmadığından bu grupta kimse bulunmamaktadır. X kuşağında ise katılımcıların yüzde 5,1'i (8 kişi) 0 - 5 yıllık çalışan, yüzde 5,5'sı (7 kişi) 6 yıl - 10 yıl arası çalışan, yüzde 27,9'sı (17 kişi 11 yıl - 15 yıl arası çalışan, yüzde 68,8'si (22 kişi) 16 yıl - 20 yıl arası çalışan, yüzde 96,9'u (31 kişi) 21 yıl - 25 yıl arası çalışan yüzde 12.8 'i (37 kişi) 26 yıl ve daha fazla süredir çalışanlardan oluşmaktadır.

\subsection{Analiz Stratejisi}

$\mathrm{Bu}$ çalışmada model analizlerinin test edilmesinde "temel bileşenler analizi" kullanımına ağırlık verilmiştir. Temelde "çoklu doğrusal regresyon" olarak tanımlanan model, iki grupta regresyon katsayılarının eşit olup olmadığını belirlemeye odaklanmış olduğu için "regresyonların eşitliği testi” olarak adlandırılmaktadır (Şimşek, 2007).

Bu analizlerde, eş zamanlı tahmin ile modeldeki üç bağımsız değişken olan algılanan liderlik stili faktörlerinin, bağımlı değişken olan iş yaşam kalitesi, $\mathrm{X}$ ve $\mathrm{Y}$ kuşağı gruplarında benzer şekilde incelenip etkileri anlaşılmaya çalışılmıştır. Ancak regresyon analizlerinde ölçeklerin geçerlik ve güvenirlikleri önemli olduğu için, analiz öncesinde geleneksel faktör analizi yaklaşımı ile ön analizlerin yapılmasının, yani kapalı yapıların analizlerle 
yeniden değerlendirilmesi gereklidir. Bu nedenle bu çalışmada da model testinden önce her bir yapının açıklayıcı faktör analizleri yapılarak tek boyutluluk varsayımının karşılanıp karşılanmadığı anlaşılmaya çalışılacak ve sonrasında temel bileşenler analizi gerçekleştirilecektir.

\subsection{Analiz Modeli}

Şekil 1- Kuşaklar Bazında Liderlik Türleri ve İş Yaşam Stili

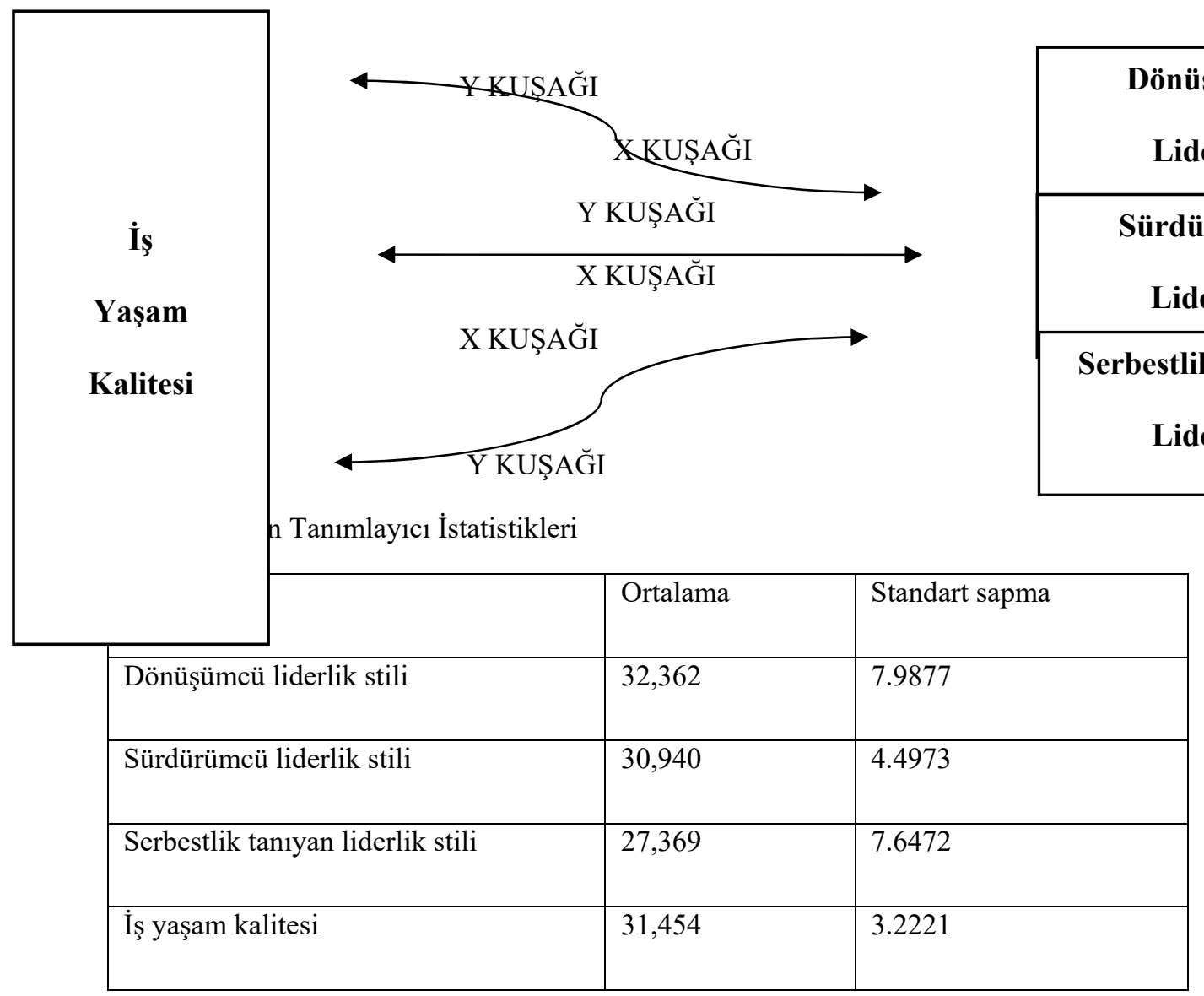

Araştırma sonucunda elde edilen ortalamalar Tablo 5'te belirtilmiştir. Dönüşümcü liderlik ortalaması 32,36, sürdürümcü liderlik ortalaması 30,940 ve serbestlik tanıyan liderlik ortalaması 27,369 olarak belirlenmiștir. Görüldüğü gibi ortalamalar arasında büyük bir fark yoktur. En yüksek ortalama dönüşümcü liderlik stili için, en düşük ortalama ise serbestlik tanıyan liderlik stili için söz konusudur.

Araştırmaya katılan tüm çalışanların birlikte değerlendirildiği iş yaşam kalitesi düzeyi ortalaması ise 31,454 'dür.

\subsection{Analiz Sonuçları}

Cattel tarafından ortaya atılan Scree-Testi faktör sayısını belirlemede kullanılmaktadır. Bu yöntemde öz-değerler y ekseninde ve bu değerlerin sıra numaraları x ekseninde gösterilir. Faktör sayısını belirlemek için grafiğin dirsek şeklini aldığı nokta referans alınır. Bu nokta aynı zamanda grafiğin düz bir çizgiye benzemeye başladığı noktadır. 
Tablo 6 - Algılanan Liderlik Stili Ölçeğinin Maddelerinin Faktör Yükleri

\begin{tabular}{|c|c|c|c|c|}
\hline \multirow{2}{*}{$\begin{array}{c}\text { Soru } \\
\text { Numaralar1 }\end{array}$} & \multirow{2}{*}{ Algılanan Liderlik Stili Ölçeği } & \multicolumn{3}{|c|}{ Bileşen } \\
\hline & & Faktör 1 & Faktör 2 & Faktör 3 \\
\hline 2 & $\begin{array}{l}\text { Kritik kararları uygunluğunu sorgulayarak tekrar gözden } \\
\text { geçirir. }\end{array}$ & 0,545 & & \\
\hline 3 & Sorunlar ciddileşmeden karışmaz. & & 0,635 & \\
\hline 6 & Kendisi için çok önemli olan değer ve inançlardan bahseder. & 0,730 & & \\
\hline 9 & Gelecek hakkında iyimser konuşmalar yapar. & 0,710 & & \\
\hline 10 & Çalışanları kendisiyle işbirliği içinde oldukları için över. & 0,657 & & \\
\hline 11 & $\begin{array}{l}\text { Amaçlanan hedeflere ulaşmak için, çalışanların } \\
\text { sorumluluklarını detaylı bir biçimde belirler. }\end{array}$ & & 0,725 & \\
\hline 13 & Başarıya ulaşmak için güdüleyici konuşmalar yapar. & 0,728 & & \\
\hline 14 & $\begin{array}{l}\text { Güçlü bir hedefe ulaşma anlayışına sahip olmanın önemini } \\
\text { vurgular. }\end{array}$ & 0,724 & & \\
\hline 15 & $\begin{array}{l}\text { Çalışanları eğitmek ve onlara yardımcı olmak için zaman } \\
\text { harcar. }\end{array}$ & 0,801 & & \\
\hline 16 & $\begin{array}{l}\text { Hedeflenen performans sonuçlarına ulaşmak için, çalışanların } \\
\text { beklentilerinin neler olduğunu öğrenir ve onlardan neler } \\
\text { beklendiğini açıça belirtir. }\end{array}$ & & 0,807 & \\
\hline 17 & "Bozuk değilse tamir etme" söyleminin savunucusudur. & & & 0,618 \\
\hline 18 & Grubun iyiliği için kendi menfaatlerinden vazgeçer. & 0,676 & & \\
\hline 21 & $\begin{array}{l}\text { Başkalarının ona saygı göstermesini sağlayacak şekilde rol } \\
\text { yapar. }\end{array}$ & & 0,755 & \\
\hline 23 & Kararların manevi ve etik sonuçlarını göz önünde bulundurur. & 0,630 & & \\
\hline 25 & Güç ve Güven duygusu sergiler. & 0,764 & & \\
\hline 26 & Kurum vizyonunu vurgular. & & 0,686 & \\
\hline 27 & $\begin{array}{l}\text { Dikkatini, hata ve başarısızlıkların en aza indirilmesi ve } \\
\text { standartlara kavuşması için toplar. }\end{array}$ & & 0,760 & \\
\hline 29 & $\begin{array}{l}\text { Bireyin farklı ihtiyaç, kabiliyet ve isteklerine sahip olduğunu } \\
\text { düşünür. }\end{array}$ & 0,706 & & \\
\hline 30 & Çalışanların sorunlara farklı açılardan bakmalarını sağlar. & 0,782 & & \\
\hline 31 & $\begin{array}{l}\text { Çalışanlara kendilerini geliştirmeleri için firsatlar yaratır ve } \\
\text { destekler. }\end{array}$ & 0,820 & & \\
\hline 32 & $\begin{array}{l}\text { Çalışanlara görevlerin nasıl tamamlanacağı konusunda yeni } \\
\text { bakış açıları önerir. }\end{array}$ & 0,823 & & \\
\hline 34 & Ortak görev anlayışını vurgular. & 0,757 & & \\
\hline 35 & $\begin{array}{l}\text { Çalışanlar beklentilerine kavuştuklarında memnuniyetini } \\
\text { ifade eder. }\end{array}$ & 0,774 & & \\
\hline 36 & Hedeflere ulaşılacağına dair güven oluşturur. & 0,816 & & \\
\hline
\end{tabular}

Analizler sonucunda dönüşümcü liderlik faktöründe $2,6,9,10,13,14,15,23,25,29,30,31,32,34,35,36$ maddeleri sürdürümcü liderlik faktöründe $3,11,16,21,26,27$ maddeleri ve serbestlik tanıyan liderlik faktöründe de 17 maddesinin yer aldığı belirlenmiştir.

Varimax yöntemi ile faktör yükü düşük olan sorular çıkarılarak, bu işlem tekrarlandığında Component Correlation Matrix de değerlerin 0,30'dan düşük olduğu faktörlerinin soruları çıkarılarak analiz tekrar yapıldı ve yukarıdaki tablo elde edilmiştir. 
Şekil 2- Algılanan Liderlik Ölçeğinin Maddelerine İlişkin Scree-Test Sonucu

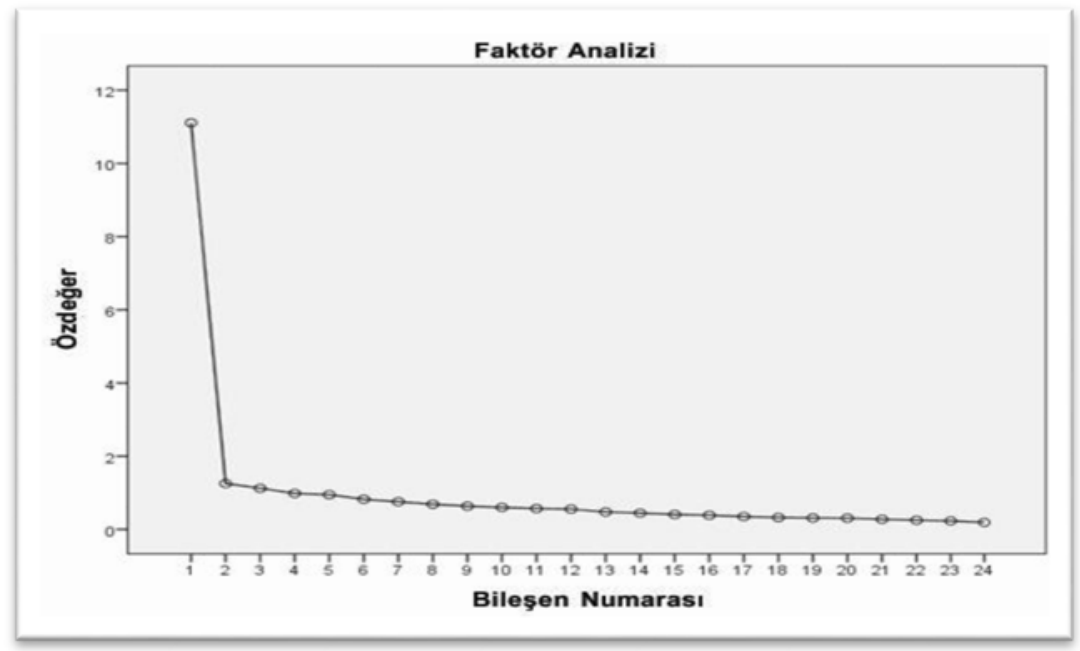

Tablo 7 - Bileşenlerin Oransal Veri Tablosu

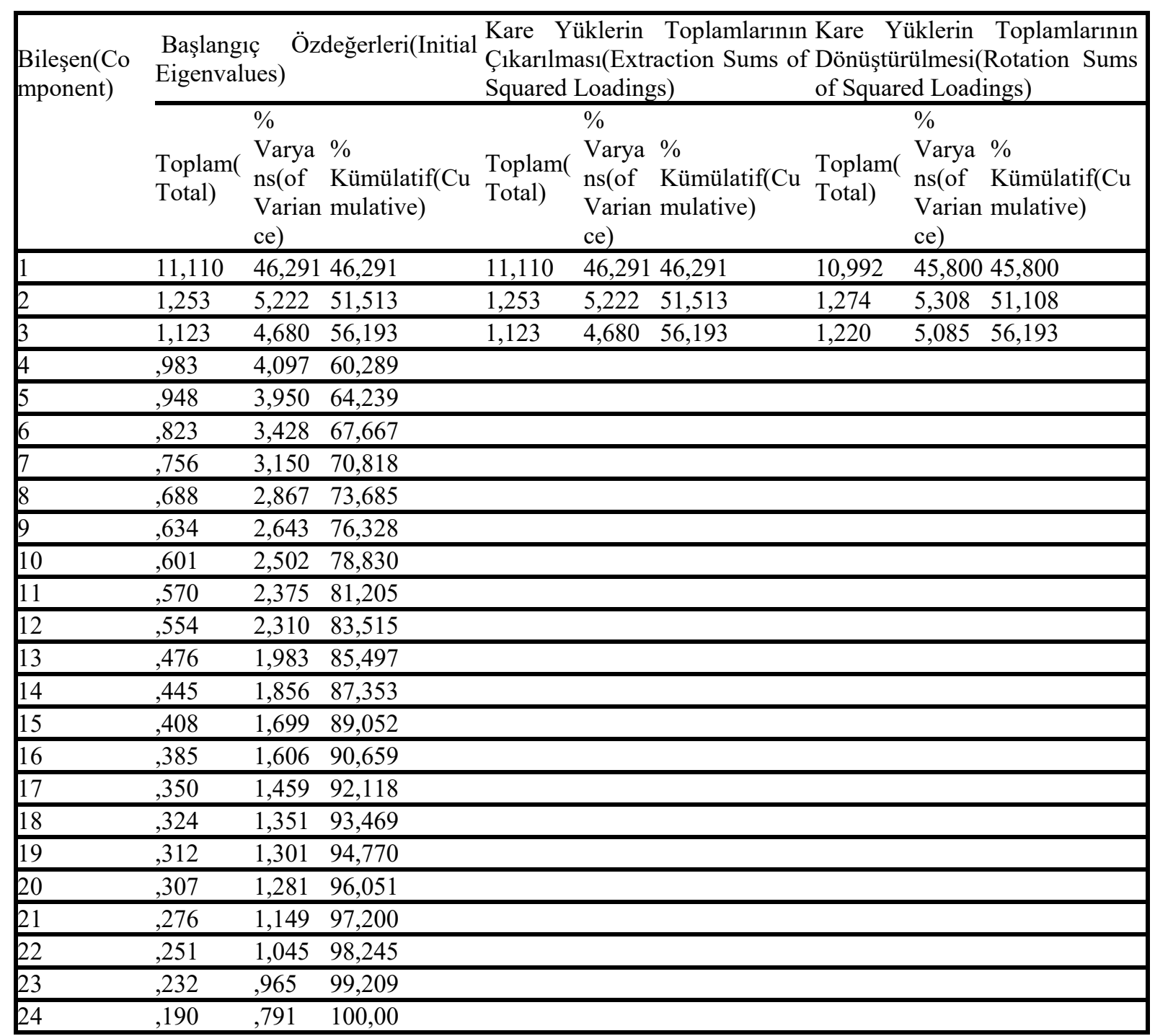


Tablo 8- İş Yaşam Kalitesi Ölçeğinin Faktör Yükleri (Ekstraksiyon Metodu: Temel Bileşen Analizi)

\begin{tabular}{|c|c|c|}
\hline İş Yaşam Kalitesi Ölçeğinin Faktör Yükleri & Başlangıç & Ç1karım \\
\hline 1- Genel anlamda, işimi eğlenceli buluyorum. & 1,000 & 559 \\
\hline $\begin{array}{l}\text { 2- Eğitim niteliklerim ve/veya becerilerim dikkate alındığında, maaşım olması } \\
\text { gerektiğinden daha az. }\end{array}$ & 1,000 & ,567 \\
\hline 3- Müdürümden/amirimden işim ile ilgili aldığım geri bildirim yapıcıdır. & 1,000 & ,561 \\
\hline 4- İşim konusunda daha fazla sorumluluk alabiliyor olmayı isterim. & 1,000 &, 555 \\
\hline 5- Bütün olarak bakıldığında, kurumumun işleri hakkında yeterince bilgi sahibiyim. & 1,000 & 610 \\
\hline 6- İşimin bana güvenli bir gelecek sağladığını düşünüyorum. & 1,000 & ,558 \\
\hline 7- İşyerimde iş arkadaşlarım bana destek olurlar. & 1,000 & ,634 \\
\hline 8- İşyerinde karar alma sürecinde bana daha fazla firsat tanınması isterim. & 1,000 &, 575 \\
\hline 9- İşim genellikle benim için bir stres kaynağıdır. & 1,000 & ,546 \\
\hline 10- İyi yaptığım işler için daha fazla övgü almak isterim. & 1,000 & ,439 \\
\hline 11- Meslektaşlarım arasında genellikle iyi bir işbirliği duygusu hakimdir. & 1,000 & ,626 \\
\hline 12- İşim, becerilerimi ve yeteneklerimi tam olarak kullanma imkanı sunmuyor. & 1,000 & ,508 \\
\hline $\begin{array}{l}\text { 13- Müdürüm/amirim bana rehberlik edecek ve bana tavsiyelerde bulunacak yeterli } \\
\text { bilgiye sahiptir. }\end{array}$ & 1,000 & ,593 \\
\hline $\begin{array}{l}\text { 14- Bask1 altında olduğumda, bu genellikle fark edilir ve müdürüm/amirim bununla } \\
\text { ilgilenir. }\end{array}$ & 1,000 & ,523 \\
\hline 15- Kurumumun aldığı kararlar hakkında daha iyi bilgilendirilebilirim. & 1,000 & 641 \\
\hline 16- Daha önceki iş deneyimime bakıldığında maaşım makul seviyededir. & 1,000 & ,655 \\
\hline 17- İşteyken kendimi daima yorgun hissediyorum. & 1,000 & ,548 \\
\hline 18- İşim hakkında yeterince geri bildirim almadığımı düşünüyorum. & 1,000 & 469 \\
\hline 19- İşim, en iyi olduğum alanda çalışmama imkan tanıyor. & 1,000 & ,517 \\
\hline 20- Müdürümle/amirimle konuşmakta zorlanıyorum. & 1,000 & ,561 \\
\hline $\begin{array}{l}\text { 21- Kurumumun yerine getirdiği işlerin farklı yönlerine dahil olma şansımın fazla } \\
\text { olmasını isterim. }\end{array}$ & 1,000 & ,601 \\
\hline 22- İşim aracılığıyla benim kişisel ilgi alanıma giren alanları takip edebiliyorum. & 1,000 & ,491 \\
\hline 23- İş arkadaşlarım ile iyi ilişkilerim var. & 1,000 & ,643 \\
\hline 24- İște olduğum zaman genellikle kendimi stresli hissediyorum. & 1,000 & ,692 \\
\hline 25- Maaşım, yaptığım iş türüne göre makul seviyededir. & 1,000 & ,708 \\
\hline $\begin{array}{l}\text { 26- Bazen, fiziki sağlığımın çalışma ortamım yüzünden bozulabileceği hissine } \\
\text { kapılıyorum. }\end{array}$ & 1,000 & ,598 \\
\hline 27- Kurumumun hedefleri hakkında bilgi sahibiyim. & 1,000 & ,623 \\
\hline 28- İşim bana olumlu etkilere yol açan güçlükler sunmaktadır. & 1,000 & 491 \\
\hline 29- Müdürüm/amirim tüm çalışanları ile adil olarak ilgilenir. & 1,000 & ,649 \\
\hline 30- İşi zamanında bitirmek için çoğunlukla eve iş götürüyorum. & 1,000 & ,570 \\
\hline $\begin{array}{l}\text { 31- Maaşım dışında, ayrıca sunulan imkânlar(ör. emekli aylığı, sağlık hizmetleri) } \\
\text { yeterlidir. }\end{array}$ & 1,000 & ,468 \\
\hline 32- Her zaman iş yerimde ne yapacağım söyleniyor. & 1,000 & ,559 \\
\hline 33-İsş konusundaki endişelerim yüzünden uykuya dalma gibi bir sorun yaş1yorum. & 1,000 & ,622 \\
\hline 34- İş arkadaşlarımla iyi ilişkiler kurmak için az fırsat mevcut. & 1,000 &, 578 \\
\hline 35- Müdürüm/amirim bana ihtiyacım olan tüm danışmanlığg sunuyor. & 1,000 & ,686 \\
\hline $\begin{array}{l}\text { 36- İşyerimdeki değişikliklerin, yakında başka bir iş aramak zorunda kalacağım } \\
\text { anlamına geldiğini düşünüyorum. }\end{array}$ & 1,000 & ,538 \\
\hline 37- Müdürüm/amirim farklı çalışma şekillerine açıktır. & 1,000 & ,625 \\
\hline 38- İşimin daha ilham verici olmasını isterdim. & 1,000 & 530 \\
\hline 39- Maaşım, sorumluluklarıma göre uygundur. & 1,000 & ,764 \\
\hline 40- Çoğunlukla geceleri işim hakkında endişe duyarak uyanırım. & 1,000 & ,634 \\
\hline
\end{tabular}

Faktör yükü düşük olan madde çıkarılarak, bu işlem tekrarlandığında Component Correlation Matrix'de değerlerin 0,30 'dan düşük olduğu faktörlerin soruları çıkarılarak analiz tekrar yapıldı ve yukarıdaki tablo elde edildi. 


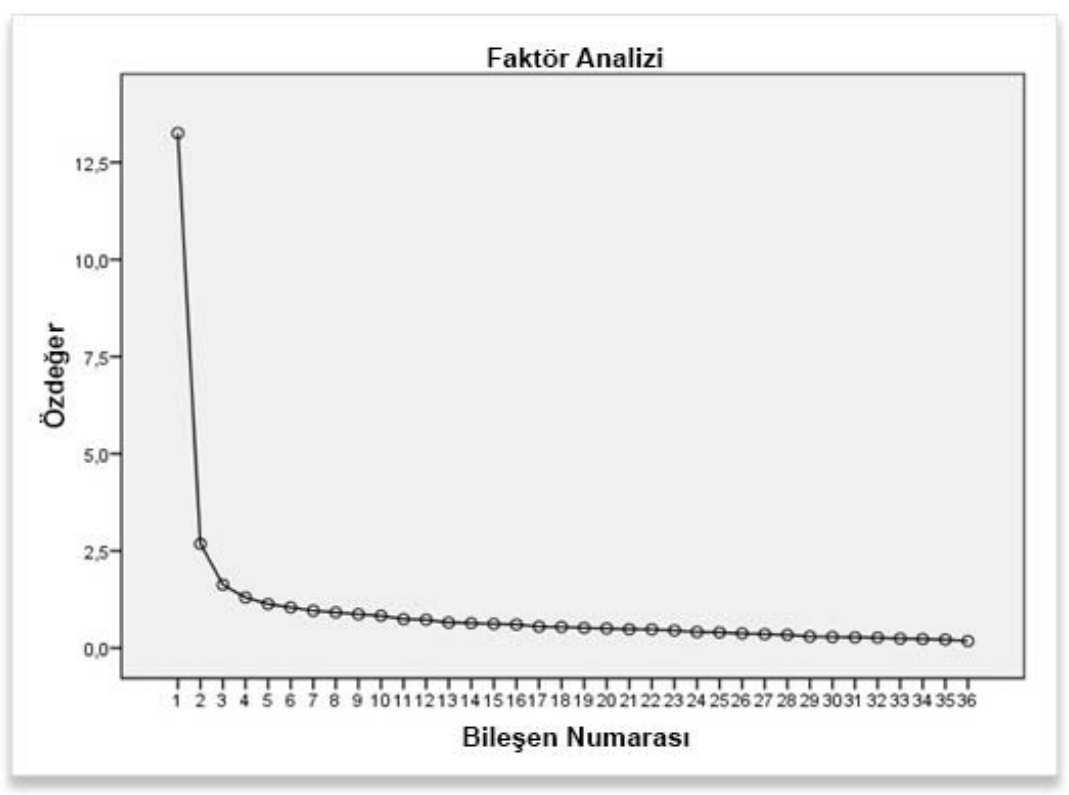

Faktör analizinde faktör sayısı belirlenirken birden çok teknik kullanılır. Faktör yapısını belirlerken bu tablo da fikir verir. İki nokta arası bir faktörü ifade eder. Bu tabloda eğrinin düzleşerek devam ettiği nokta bulunur ve kaç faktör olduğu sayılır. Bu noktaya plato değeri denir. Yukarıdaki tabloda da görüldüğü gibi 3 faktör vardır ve özdeğeri 1'den büyük olanlar faktör olur.

\section{Demografik Değişkenlere İlişkin Karşılaştırmalar}

P değeri küçüldükçe istatistiksel olarak anlamlı farklılığın kanıtı artar. P değeri 0,01 ile 0,05 aralığında olduğunda istatistiksel olarak anlamlı fark vardır. P değeri 0,001 ile 0,01 aralığında olduğunda ise yüksek düzeyde anlamlı fark vardır. P değeri 0,001 den daha küçük ise; çok yüksek düzeyde istatistiksel olarak anlamlı fark vardır. P değeri 0,10 ile 0,05 aralığında ise sınırda anlamlılık olduğu yani “marginally significant” anlamına gelmektedir. Bu analiz için p değeri 0,05 kabul edilmiştir ve hipotezlerin testi bu p değerine göre yapılmıştır.

Tablo 9- Cinsiyetin Algılanan Liderlik Stili ve İş Yaşam Kalitesi Üzerindeki Etkisi - Anova Tablosu

\begin{tabular}{|c|c|c|c|c|}
\hline & & Df & $\mathrm{F}$ & Sig. \\
\hline \multirow{3}{*}{ Dönüşümcü Liderlik Stili } & GRUP İÇİ & 445 & \multirow{2}{*}{,248 } & \multirow{2}{*}{,619 } \\
\hline & GRUPLAR ARASI & 1 & & \\
\hline & TOPLAM & 446 & & \\
\hline \multirow{3}{*}{$\begin{array}{l}\text { Sürdürümcü } \\
\text { Liderlik Stili }\end{array}$} & GRUP İÇİ & 445 & \multirow{2}{*}{1,360} & \multirow{2}{*}{,244 } \\
\hline & GRUPLAR ARASI & 1 & & \\
\hline & TOPLAM & 446 & & \\
\hline \multirow{3}{*}{$\begin{array}{l}\text { Serbestlik Tanıyan Liderlik } \\
\text { Stili }\end{array}$} & GRUP İÇİ & 445 & \multirow{2}{*}{,016 } & \multirow{2}{*}{,901 } \\
\hline & GRUPLAR ARASI & 1 & & \\
\hline & TOPLAM & 446 & & \\
\hline \multirow{3}{*}{ İş Yaşam Kalitesi } & GRUP İÇİ & 445 & \multirow{2}{*}{,053 } & \multirow{2}{*}{,818 } \\
\hline & GRUPLAR ARASI & 1 & & \\
\hline & TOPLAM & 446 & & \\
\hline
\end{tabular}


Tek yönlü ANOVA sonucunda dönüşümcü liderlik açısından cinsiyetler arasında anlamlı bir farklılık olmadığ görülmektedir $(\mathrm{F}=0,248 ; \mathrm{p}=0,619>0,05)$. Yani, bir kişinin cinsiyetinin erkek veya kadın olmasının onun dönüşümcü liderlik stili algısına istatistiksel olarak anlamlı bir katkısı olmayacaktır.

Tek yönlü ANOVA sonucunda sürdürümcü liderlik açısından cinsiyetler arasında anlamlı bir farklılık olmadığı görülmektedir $(\mathrm{F}=1,360 ; \mathrm{p}=0,244>0,05)$. Bir kişinin cinsiyetinin yani erkek veya kadın olmasının onun sürdürümcü liderlik stili algısına istatistiksel olarak anlamlı bir katkısı olmayacaktır.

Tek yönlü ANOVA sonucunda serbestlik tanıyan liderlik açısından cinsiyetler arasında anlamlı bir farklılık olmadığı görülmektedir $(\mathrm{F}=0,016 ; \mathrm{p}=0,901>0,05)$. Yani, bir kişinin cinsiyetinin erkek veya kadın olmasının onun serbestlik tanıyan liderlik stili algısına istatistiksel olarak anlamlı bir katkısı olmayacaktır.

Tek yönlü ANOVA sonucunda iş yaşam kalitesi açısından cinsiyetler arasında anlamlı bir farklılık olmadığı görülmektedir $(\mathrm{F}=0,053 ; \mathrm{p}=0,818>0,05)$. Yani, bir kişinin cinsiyetinin onun iş yaşam kalitesine istatistiksel olarak anlamlı bir katkısı olmayacaktır.

Tablo 10 - Medeni durumun Algılanan Liderlik Stili ve İş Yaşam Kalitesi Üzerindeki Etkisi - Anova Tablosu

\begin{tabular}{|c|c|c|c|c|}
\hline & & Df & $\mathrm{F}$ & Sig. \\
\hline \multirow{3}{*}{ Dönüşümcü Liderlik Stili } & GRUP İÇİ & 445 & \multirow{2}{*}{,033 } & \multirow{2}{*}{,856 } \\
\hline & GRUPLAR ARASI & 1 & & \\
\hline & TOPLAM & 446 & & \\
\hline \multirow{3}{*}{ Sürdürümcü Liderlik Stili } & GRUP İÇİ & 445 & \multirow{2}{*}{1,628} & \multirow{2}{*}{ 203 } \\
\hline & GRUPLAR ARASI & 1 & & \\
\hline & TOPLAM & 446 & & \\
\hline \multirow{3}{*}{ Serbestlik Tanıyan Liderlik Stili } & GRUP İÇİ & 445 & \multirow{2}{*}{,069 } & \multirow{2}{*}{,792 } \\
\hline & GRUPLAR ARASI & 1 & & \\
\hline & TOPLAM & 446 & & \\
\hline \multirow{3}{*}{ İş Yaşam Kalitesi } & GRUP İÇİ & 445 & \multirow{2}{*}{,154 } & \multirow{2}{*}{ 695 } \\
\hline & GRUPLAR ARASI & 1 & & \\
\hline & TOPLAM & 446 & & \\
\hline
\end{tabular}

Tek yönlü ANOVA sonucunda dönüşümcü liderlik açısından medeni durum arasında anlamlı bir farklılık olmadığ1 görülmektedir ( $\mathrm{F}=0,33 ; \mathrm{p}=0,856>0,05)$. Yani, kişinin medeni durumunun, onun dönüşümcü liderlik stili algısına istatistiksel olarak anlamlı bir katkısı yoktur.

Tek yönlü ANOVA sonucunda sürdürümcü liderlik açısından medeni durum arasında anlamlı bir farklılık olmadığ görülmektedir $(\mathrm{F}=1,628 ; \mathrm{p}=0,203>0,05)$. Yani, kişinin medeni durumunun, onun sürdürümcü liderlik stili algisına istatistiksel olarak anlamlı bir katkısı yoktur.

Tek yönlü ANOVA sonucunda serbestlik tanıyan liderlik açısından medeni durum arasında anlamlı bir farklılık olmadığı görülmektedir $(\mathrm{F}=0,69 ; \mathrm{p}=0,792>0,05)$. Yani, kişinin medeni durumunun, onun serbestlik tanıyan liderlik stili algisina istatistiksel olarak anlamlı bir katkısı yoktur.

Tek yönlü ANOVA sonucunda iş yaşam kalitesi açısından medeni durum arasında anlamlı bir farklılık olmadı̆ğ görülmektedir ( $\mathrm{F}=0,154 ; \mathrm{p}=0,695>0,05)$. Yani, kişinin medeni durumunun, onun iş yaşam kalitesine istatistiksel olarak anlamlı bir katkısı yoktur.

Tablo 11 - Eğitim Düzeyinin Algılanan Liderlik Stili ve İş Yaşam Kalitesi Üzerindeki Etkisi - Anova Tablosu

\begin{tabular}{|l|l|l|l|l|}
\hline & & Df & F & Sig. \\
\hline \multirow{2}{*}{ Dönüşümcü Liderlik Stili } & GRUP IÇ்̇ & 445 & \multirow{2}{*}{4,702} & \multirow{2}{*}{, 003} \\
\cline { 2 - 3 } & GRUPLAR ARASI & 1 & & \\
\hline
\end{tabular}




\begin{tabular}{|c|c|c|c|c|}
\hline & TOPLAM & 446 & & \\
\hline \multirow{3}{*}{ Sürdürümcü Liderlik Stili } & GRUP İÇİ & 445 & \multirow{2}{*}{8,834} & \multirow{2}{*}{, 00} \\
\hline & GRUPLAR ARASI & 1 & & \\
\hline & TOPLAM & 446 & & \\
\hline \multirow{3}{*}{ Serbestlik Tanıyan Liderlik Stili } & GRUP İÇİ & 445 & \multirow{2}{*}{1,079} & \multirow{2}{*}{, 35} \\
\hline & GRUPLAR ARASI & 1 & & \\
\hline & TOPLAM & 446 & & \\
\hline \multirow{3}{*}{ İş Yaşam Kalitesi } & GRUP İÇİ & 445 & \multirow{2}{*}{9,801} & \multirow{2}{*}{, 00} \\
\hline & GRUPLAR ARASI & 1 & & \\
\hline & TOPLAM & 446 & & \\
\hline
\end{tabular}

Tek yönlü ANOVA sonucunda dönüşümcü liderlik açısından eğitim düzeyleri arasında anlamlı bir farklılık olduğu görülmektedir $(\mathrm{F}=4,702 ; \mathrm{p}=0,003<0,05)$. Yani kişinin eğitim düzeyi değiştikçe, onun dönüşümcü liderlik stili algısı da değişmektedir. Tek yönlü ANOVA sonucunda sürdürümcü liderlik açısından eğitim düzeyleri arasında anlamlı bir farkl1lık olduğu görülmektedir $(\mathrm{F}=8,834 ; \mathrm{p}=0,000<0,05)$. Bu demek oluyor ki; sürdürümcü liderlik stili algıS1, eğitim seviyesine göre değişmektedir.

Tek yönlü ANOVA sonucunda serbestlik tanıyan liderlik açısından eğitim düzeyleri arasında anlamlı bir farklılık olmadığı görülmektedir $(F=1,079 ; \mathrm{p}=0,358>0,05)$. Yani, kişilerin serbestlik tanıyan liderlik stili algısını, eğitim seviyesi değiştirmemektedir.

Tek yönlü ANOVA sonucunda iş yaşam kalitesi açısından eğitim düzeyleri arasında anlamlı bir farklılık olduğu görülmektedir $(\mathrm{F}=9,801 ; \mathrm{p}=0,000<0,05)$. Yani, kişilerin iş yaşam kaliteleri, eğitim seviyelerine göre değişmektedir.

Tablo 12 - Mesleğin Algılanan Liderlik Stili ve İş Yaşam Kalitesi Üzerindeki Etkisi - Anova Tablosu

\begin{tabular}{|c|c|c|c|c|}
\hline & & Df & $\mathrm{F}$ & Sig. \\
\hline \multirow{3}{*}{ Dönüşümcü Liderlik Stili } & GRUP İÇİ & 445 & \multirow{2}{*}{29,794} & \multirow{2}{*}{,000 } \\
\hline & GRUPLAR ARASI & 1 & & \\
\hline & TOPLAM & 446 & & \\
\hline \multirow{3}{*}{ Sürdürümcü Liderlik Stili } & GRUP İÇİ & 445 & \multirow{2}{*}{21,807} & \multirow{2}{*}{,000 } \\
\hline & GRUPLAR ARASI & 1 & & \\
\hline & TOPLAM & 446 & & \\
\hline \multirow{3}{*}{ Serbestlik Tanıyan Liderlik Stili } & GRUP İÇİ & 445 & \multirow{2}{*}{3,725} & \multirow{2}{*}{,054 } \\
\hline & GRUPLAR ARASI & 1 & & \\
\hline & TOPLAM & 446 & & \\
\hline \multirow{3}{*}{ İş Yaşam Kalitesi } & GRUP İÇİ & 445 & \multirow{2}{*}{12,098} & \multirow{2}{*}{,001 } \\
\hline & GRUPLAR ARASI & 1 & & \\
\hline & TOPLAM & 446 & & \\
\hline
\end{tabular}

Tek yönlü ANOVA sonucunda dönüşümcü liderlik açısından mesleklerin arasında anlamlı bir farklılık olduğu görülmektedir $(\mathrm{F}=29,794 ; \mathrm{p}=0,000<0,05)$. Diğer bir deyişle, kişilerin mesleklerinin, dönüşümcü liderlik stili algıları üzerinde istatistiksel olarak önemli derecede bir etkisi vardır.

Tek yönlü ANOVA sonucunda sürdürümcü liderlik açısından mesleklerin arasında anlamlı bir farklılık olduğu görülmektedir $(\mathrm{F}=21,807 ; \mathrm{p}=0,000<0,05)$. Yani, kişilerin meslekleri ile sürdürümcü liderlik stili algıları arasında istatistiksel olarak önemli derecede bir ilişki vardır. 
Tek yönlü ANOVA sonucunda serbestlik tanıyan liderlik açısından mesleklerin arasında anlamlı bir farklılık olmadığı görülmektedir $(\mathrm{F}=3,725 ; \mathrm{p}=0,054>0,05)$. Yani, kişilerin mesleklerinin, kişilerin serbestlik tanıyan liderlik stili algıları üzerinde istatistiksel olarak anlamlı bir etkisi yoktur.

Tek yönlü ANOVA sonucunda iş yaşam kalitesi açısından mesleklerin arasında anlamlı bir farklılık olduğu görülmektedir $(\mathrm{F}=12,098 ; \mathrm{p}=0,001<0,05)$. Yani, mesleklerin iş yaşam kalitesine istatistiksel olarak anlamlı bir etkisi bulunmamaktadır.

Tablo 13 - Mesleki kıdemin Algılanan Liderlik Stili ve İş Yaşam Kalitesi Üzerindeki Etkisi - Anova Tablosu

\begin{tabular}{|c|c|c|c|c|}
\hline & & Df & $\mathrm{F}$ & Sig. \\
\hline \multirow{3}{*}{ Dönüşümcü Liderlik Stili } & GRUP İÇİ & 445 & \multirow[t]{2}{*}{,968 } & \multirow[t]{2}{*}{,437 } \\
\hline & GRUPLAR ARASI & 1 & & \\
\hline & TOPLAM & 446 & & \\
\hline \multirow{3}{*}{ Sürdürümcü Liderlik Stili } & GRUP İÇİ & 445 & \multirow{2}{*}{4,048} & \multirow{2}{*}{001} \\
\hline & GRUPLAR ARASI & 1 & & \\
\hline & TOPLAM & 446 & & \\
\hline \multirow{3}{*}{ Serbestlik Tanıyan Liderlik Stili } & GRUP İÇİ & 445 & \multirow{2}{*}{, 859} & \multirow{2}{*}{, 509} \\
\hline & GRUPLAR ARASI & 1 & & \\
\hline & TOPLAM & 446 & & \\
\hline \multirow{3}{*}{ İş Yaşam Kalitesi } & GRUP İÇİ & 445 & \multirow{3}{*}{, 852} & \multirow{3}{*}{, 513} \\
\hline & GRUPLAR ARASI & 1 & & \\
\hline & TOPLAM & 446 & & \\
\hline
\end{tabular}

Tek yönlü ANOVA sonucunda dönüşümcü liderlik açısından mesleki kıdem arasında anlamlı bir farklılık olmadığı görülmektedir $(\mathrm{F}=0,968 ; \mathrm{p}=0,437>0,05)$. Yani, mesleki kıdemin dönüşümcü liderlik stili algısı üzerine istatistiksel olarak anlamlı bir etkisi yoktur.

Tek yönlü ANOVA sonucunda sürdürümcü liderlik açısından mesleki kıdem arasında anlamlı bir farklılık olduğu görülmektedir $(\mathrm{F}=4,048 ; \mathrm{p}=0,001<0,05)$. Bu demek oluyor ki; kişilerin mesleki kıdemleri, onların sürdürümcü liderlik stili algılarını istatistiksel olarak anlamlı derecede etkilemektedir.

Tek yönlü ANOVA sonucunda serbestlik tanıyan liderlik açısından mesleki kıdem arasında anlamlı bir farklılık olmadığ görülmektedir $(F=0,859 ; p=0,509>0,05)$. Diğer bir deyişle, kişinin mesleki kıdemi, onun serbestlik tanıyan liderlik stili algısını istatistiksel olarak anlamlı derecede etkilememektedir.

Tek yönlü ANOVA sonucunda iş yaşam kalitesi açısından mesleki kıdem arasında anlamlı bir farklılık olmadığı görülmektedir $(\mathrm{F}=0,852 ; \mathrm{p}=0,513>0,05)$. Yani, kişilerin mesleki kıdemleri, onların iş yaşam kalitesini istatistiksel olarak önemli derecede etkilememektedir.

Analizlere devam edebilmek için veri setin normallik varsayımını sağlaması gerekmektedir. Normallik sınaması için yapılan testler içinde Kolmogrov Smirnov ya da Shapiro Wilks testleri en yaygın testlerdir. Bu testlerin sonucunda significant değerlerinin anlamsız çıkması beklenir. ( $\mathrm{p}>0,05$ olmalıdır) $\mathrm{Bu}$ araştırmada, normallik sınaması için her iki test sonucu da aşağıdaki tabloda verilmiştir.

Tablo 14- Ölçekler İçin Normallik Testi

\begin{tabular}{|c|c|c|}
\hline Ölçekler & Kolmogrov-Smirnov & Shapirp-Wilk \\
\hline & Sig. & Sig. \\
\hline İş Yaşam kalitesi & 0,079 & 0,066 \\
\hline Dönüşümcü liderlik & 0,081 & 0,060 \\
\hline Serbestlik tanıyan liderlik & 0,077 & 0,067 \\
\hline Sürdürümcü Liderlik & 0,065 & 0,074 \\
\hline
\end{tabular}


Tabloda veri değerleri incelendiğinde, $\% 5$ anlamlılık düzeyinde her iki test için Sig. değerleri 0.05 den büyük çıkmıştır ve veriler normal dağılıma uymaktadır. Hesaplanan korelasyon katsayısının belirttiği ilişkinin önemli olup olmadığı başka bir ifade ile korelasyon katsayısı ile bulunan değere güvenilip güvenilemeyeceği, korelasyon katsayısının önemi testi ile belirlenir. Korelasyon katsayıs1 -1 ile +1 arasında olmalıdır. Korelasyon katsayıs1 -0,29 ile $-0,10$ arasında ise ters yönde düşük ilişki, $-0,49$ ile 0,30 arasında ise orta düzeyde ters yönce ilişki, $-0,50$ ile 1,0 arasında ise ters yönde yüksek ilişki vardır yorumları yapılır. Korelasyon katsayısı değeri 0,10 ile 0,29 arasında ise pozitif yönde düşük ilişki, 0,30 ile 0,49 arasında pozitif yönde orta derecede ilişki ve 0,50 ile 1,0 arasında ise pozitif yönde yüksek bir ilişki vardır denir. Tabloda ölçeklerin X ve Y kuşaklarında korelasyon katsayıları verilmiştir.

Tablo 151 - Kuşaklara ilişkin Pearson Korelasyon Testi Sonuçları - Y Kuşağındaki Değişkenler Arası İlişskiler

\begin{tabular}{|c|c|c|c|c|}
\hline $\begin{array}{c}\text { Kontrol } \\
\text { Değişkenleri }\end{array}$ & $\begin{array}{l}\text { Dönüşümcü } \\
\text { Liderlik }\end{array}$ & $\begin{array}{l}\text { Sürdürümcü } \\
\text { Liderlik }\end{array}$ & $\begin{array}{c}\text { Serbestlik Tanıyan } \\
\text { Liderlik }\end{array}$ & İş Yaşam Kalitesi \\
\hline $\begin{array}{l}\text { Dönüşümcü } \\
\text { Liderlik }\end{array}$ & 1 & .435 & -.516 & .471 \\
\hline $\begin{array}{l}\text { Sürdürümcü } \\
\text { Liderlik }\end{array}$ & & 1 & .117 & .493 \\
\hline $\begin{array}{c}\text { Serbestlik Tanıyan } \\
\text { Liderlik }\end{array}$ & & & 1 & .009 \\
\hline İş Yaşam Kalitesi & & & & 1 \\
\hline
\end{tabular}

(**) anlamlılık düzeyleri (alfa), hem yüzde 95 e göre anlamlı hem de yüzde 99 a göre anlamlı

Çalışmada ele alınan değişkenlerin Y kuşağında birbirleriyle ilişkilerinin düzeyini belirlemek için yapılan Pearson Korelasyon Analizi sonuçları tabloda verilmiştir. Veriler normal dağıldığı için Pearson Korelasyon Testi uygulanmıştır. Buna göre kişilerin algıladıkları dönüşümcü liderlik stili ile iş yaşam kalitesi arasında anlamlı ve orta düzeyde, sürdürümcü liderlik ile iş yaşam kalitesi arasında anlamlı ve orta düzeyde, serbestlik tanıyan liderlik ile iş yaşam kalitesi arasında zayıf fakat anlamlı ilişki vardır.

Tablo 16 - Kuşaklara ilişkin Pearson Korelasyon Testi Sonuçları - X Kuşağında Değişkenler Arası ilişkiler

\begin{tabular}{|c|c|c|c|c|}
\hline Kontrol Değişkenleri & $\begin{array}{c}\text { Dönüşümcü } \\
\text { Liderlik }\end{array}$ & $\begin{array}{c}\text { Sürdürümcü } \\
\text { Liderlik }\end{array}$ & $\begin{array}{c}\text { Serbestlik } \\
\text { Taniyan Liderlik }\end{array}$ & İş Yaşam Kalitesi \\
\hline Dönüşümcü Liderlik & 1 & .631 & -.352 & .356 \\
\hline
\end{tabular}




\begin{tabular}{|c|c|c|c|c|}
\hline Sürdürümcü Liderlik & & 1 & .083 & .353 \\
\hline $\begin{array}{c}\text { Serbestlik Tanıyan } \\
\text { Liderlik }\end{array}$ & & & 1 & .016 \\
\hline İş Yaşam Kalitesi & & & & 1 \\
\hline
\end{tabular}

(**) anlamlılık düzeyleri (alfa), hem yüzde 95 e göre anlamlı hem de yüzde 99 a göre anlamlı

Çalışmada ele alınan değiş̧kenlerin X kuşağında birbirleriyle ilişkilerinin düzeyini belirlemek için yapılan Pearson Korelasyon Analizi sonuçları tabloda verilmiştir. Buna göre dönüşümcü liderlik stili algısı ile iş yaşam kalitesi arasında anlamlı ve orta düzeyde, sürdürümcü liderlik stili algısı ile iş yaşam kalitesi arasında anlamlı ve orta düzeyde, serbestlik tanıyan liderlik stili algısı ile iş yaşam kalitesi arasında zayıf fakat anlamlı ilişki vardır.

Bu durumda $\mathrm{H}_{1}, \mathrm{H}_{2}$ ve $\mathrm{H}_{3}$ hipotezleri doğrulanmıştır.

Bu sonuçlara göre, dönüşümcü liderlik stili algısı ve serbestlik tanıyan liderlik stili algısının iş yaşam kalitesi üzerindeki etkisi gruplar arasında bir farklılık göstermemektedir. Serbestlik tanıyan liderlik stili algısı ise iş yaşam kalitesi ile açıklanan varyansa tümüyle bir katkı sağlamaktadır. Sürdürümcü liderlik stili algısının X ve $Y$ kuşakları üzerinde pozitif yönde anlamlı bir etkisi yoktur. Toplamda bu üç değişken varyansının yüzde 32'sini açıklamıştır. RMSEA (Root Mean Square Erros Of Approximation) değeri 0 ile 1 arasında değişmektedir. Değerin sıfira yaklaşması uyumun çok iyi olduğunu göstermektedir.

Bu durumda $\mathrm{H}_{6}$ ve $\mathrm{H}_{4}$ reddedilmiş, $\mathrm{H}_{5}$ kabul edilmiştir.

\section{Sonuç ve Öneriler}

Son dönemlerde ortaya konulan modern yönetim yaklaşımlarının çoğuna göre bir örgütün başarılı veya başarısız olarak nitelendirilebilmesinin temel belirleyicisi işgörenlerdir (Paşa, 2002). İş yaşam kalitesini belirleyen temel tutum işgörenin işi ile ilgili sergilediği genel memnuniyet durumunun olarak ifadesidir. Ancak işgörenin bu tutumu olumlu veya olumsuz olabileceği için, çalışanın işe ilişkin tecrübelerine bağlı oluşan ruh hali kişinin iş yaşam kalitesini daha iyi tanımlamaktadır. (Erdoğan, 1996, s. 231) Herkes gündelik iş yaşamının etkilerini evine geldiğinde ya da iş çıkışı herhangi bir sosyal ortama girdiğinde taşımaya devam eder. O yüzden iş yaşamının kişilerin genel psikolojik durumlarının en önemli belirleyicisi olduğunu söylemek yanlış olmayacaktır.

İnsanların iş yaşamlarında nitelikli olarak vakit geçirip geçirmediklerini ya da tam verimli çalışıp çalışmadıklarını belirleyen bir sürü ölçüt bulunmaktadır. Çalışanların diğer personelle olan iletişimleri, işle ilgili konularda yardımlaşmaları, yaptıkları işe karşılık aldıkları ücret ve başlarında bulunan liderin çalışanlara olan yaklaşımı gibi birçok husus çalışanların iş yaşam kalitesini etkileyen örneklerden birkaçıdır. İşgörenin işveren tarafından maddi ve manevi olarak desteklendiği oranda iş yaşam kalitesi yükselecek ve işgören daha özverili çalışmaya başlayacağ açıktır. Çünkü iş yaşam kalitesi standartları çok yüksek olmayan çalışanların psikolojik çöküntülere daha kolay girebildiği ve bu durumun iş memnuniyetsizliği ile ilişkili olduğu saptanmıştır (Miner, 1992).

Çalışmamızda algılanan liderlik stili ve iş yaşam kalitesi arasındaki ilişki X ve Y kuşakları gözetilerek incelenmiştir. Demografik faktörler dikkate alınarak kuşaklar arasında algılanan liderlik stili ve iş yaşam kalitesi arasında fark olup olmadığı araştırılmıştır. Araştırma özelinde çalışanların algıladıkları liderlik stilinin iş yaşam kalitesine olan etkisini saptamak açısından yapılan anketler bize önemli veriler sunmuştur. Değişim çağı olarak kabul edilen günümüz şartlarında işletmeler, devamlılıklarını sağlayabilmeleri adına kendilerini geliştirmek zorundadır. İş yaşam kalitesinin öneminin farkına varan işverenler şirketlerinin veya organizasyonlarının karlılığını arttırmak adına bu kavrama daha çok önem vermekte ve iş yaşam kalitesini geliştirmek adına ciddi yatırımlar yapmaktadırlar. Bu noktada sonuca ulaşmak için demografik verilere başvurulmuştur. 
Kuşakların yaş aralığı düşünüldüğünde Y Kuşağına mensup kişilerin bugün itibariyle 36 ve 37 yaşına kadar olan kısmı kapsadığı bilinmektedir. Kuşağın gelişim trendi dünyadaki teknolojinin gelişimi ve yaygınlaşması ile paraleldir. Bu çerçevede yapılan çalışmalarda teknolojik gelişmeler ve çağın getirdiği yenilikler düşünülerek $Y$ kuşağının yaşam kalitesini arttırmaya yönelik, yenilikçi ve geliştirilebilmeye açık unsurların yapılan faaliyetlerde kullanılması bir zorunluluk olarak kabul edilmelidir. İş yaşam kalitesinin yüksekliği herhangi birinin o örgüte girmek için tercih sebebi olabilir. Ama aynı zamanda o örgüt içinde bulunanların iş memnuniyetlerini ve kariyer olanaklarının da tatmin edilmesini konu almaktadır.

Ankara, İstanbul ve İzmir illerinde yaşayan X ve Y kuşağına mensup 447 kişinin kişisel ve dönemsel farklılıkları da çalıșma özelinde farklı sonuçlar elde etmemizi sağlamışıır. Çalışanların algıladıkları liderlik stilinin iş yaşam kalitelerine olan etkisinin kuşaklar bazındaki farklılıkları bu döneme kadar her ne kadar doğrudan incelenmemiş olsa da benzeri konular araştırmacılar tarafından incelenmiştir. Araştırmamızda elde ettiğimiz veriler iş yaşam kalitesi üzerine yapılacak olan çalışmalarda ilgilenenlere yol gösterici olabilecektir.

Demografik değişkenlere ilişkin karşılaştırmalara bakıldığında tek yönlü ANOVA sonucunda cinsiyet, medeni durum ile çalışanların algıladıkları dönüşümcü liderlik stili, sürdürümcü liderlik stili, serbestlik tanıyan liderlik stili ve iş yaşam kalitesi arasında anlamlı bir farklılık saptanmamıştır. Yani bir kişinin cinsiyetinin erkek veya kadın olması ya da evli veya bekâr olması istatistiksel olarak çalışanların algıladıkları dönüşümcü liderlik stili, sürdürümcü liderlik stili, serbestlik tanıyan liderlik stili ve iş yaşam kalitesi üzerinde anlamlı bir katkıya sebep olmayacaktır.

Eğitim düzeyine bakıldığında çalışanların algıladıkları dönüşümcü liderlik stili, sürdürümcü liderlik stili ve iş yaşam kalitesi arasında anlamlı bir farklılık tespit edilmiş ama algılanan serbestlik tanıyan liderlik stili ile eğitim düzeyi arasında anlamlı bir farklılık olmadığı görülmüştür. Bu demek oluyor ki kişinin eğitim düzeyi değiştikçe, onun dönüşümcü ve sürdürümcü liderlik stili algısı değişirken, serbestlik tanıyan liderlik stili algısında anlamlı bir değişim tespit edilmemiştir.

Tek yönlü ANOVA sonucunda kişilerin mesleklerinin, algıladıkları dönüşümcü liderlik stili ve sürdürümcü liderlik stili üzerinde istatistiksel olarak önemli derecede etkisi olduğu tespit edilmiş̧ir. Bu iliş̧i algılanan sürdürümcü liderlik stili açısından da söz konusudur. Fakat kişilerin meslekleri ile işs yaşam kaliteleri arasında anlamlı bir farklılı̆ga rastlanmamıştır. Yani kişilerin meslekleriyle onların algıladıkları serbestlik tanıyan liderlik stilleri ve iş yaşam kaliteleri arasında istatistiksel olarak anlamlı bir etki saptanmamıştır.

Verilere mesleki kıdem açısından bakıldığında ise çalıșanların algıladıkları dönüşümcü liderlik stili ve serbestlik tanıyan liderlik stili açısından anlamlı farklılık görülmemiştir. Fakat kişilerin mesleki kıdemlerinin onların sürdürümcü liderlik stili algıları ve iş yaşam kaliteleri üzerinde anlamlı bir etkide bulunmadığg görülmüştür.

Kuşakların birbirleri ile ilişkilerinin düzeyini belirlemek için yapılan Pearson Korelasyon Analizi sonucu X kuşağında algılanan dönüşümcü liderlik stili ile iş yaşam kalitesi arasında anlamlı ve orta düzeyde, algılanan sürdürümcü liderlik stili ile iş yaşam kalitesi arasında anlamlı ve orta düzeyde, algılanan serbestlik tanıyan liderlik stili ile iş yaşam kalitesi arasında zayıf fakat anlamlı ilişki olduğunu göstermektedir. Y kuşağında ise algılanan dönüşümcü liderlik stili ile iş yaşam kalitesi arasında anlamlı ve orta düzeyde, algılanan sürdürümcü liderlik stili ile iş yaşam kalitesi arasında anlamlı ve orta düzeyde, algılanan serbestlik tanıyan liderlik stili ile iş yaşam kalitesi arasında zayıf fakat anlamlı ilişki vardır.

$\mathrm{Bu}$ sonuçlara göre, çalışanların algıladıkları dönüşümcü liderlik ve serbestlik tanıyan liderlik stilinin iş yaşam kalitesi üzerindeki etkisi gruplar arasında bir farklılık göstermemektedir. Serbestlik tanıyan liderlik stili algısı ise iş yaşam kalitesi ile açıklanan varyansa tümüyle bir katkı sağlamaktadır. Sürdürümcü liderlik stili algısının X ve Y kuşakları üzerinde pozitif yönde anlamlı bir etkisi yoktur. Toplamda bu üç değişken varyansının yüzde 32'sini açıklamıştır.

Araştırma sonucu elde edilen ortalamalara bakıldığında dönüşümcü liderlik stili ortalaması 32,36, sürdürümcü liderlik stili ortalaması 30,940 ve serbestlik tanıyan liderlik stili ortalaması 27,369 olarak belirlenmiștir. Ortalamalar arasında belirgin bir farklılık olmamakla birlikte, en yüksek ortalama dönüşümcü liderlik stili için, en düşük ortalama ise serbestlik tanıyan liderlik stili için söz konusu olmaktadır. Araştırmaya katılan tüm çalışanların birlikte değerlendirildiği iş yaşam kalitesi düzeyi ortalaması ise 31,454'dür. Araştırma hipotezinin sonuçlarına bakıldığında ise;

$\mathrm{H}_{1}$ numaralı hipotez olan dönüşümcü liderlik stili algısı ile iş yaşam kalitesi arasında anlamlı bir ilişki vardir.

$\mathrm{H}_{2}$ numaralı hipotez olan sürdürümcü liderlik stili algısı ile iş yaşam kalitesi arasında anlamlı bir ilişki vardır. 

ilişsi vardır.

$\mathrm{H}_{3}$ numaralı hipotez olan serbestlik tanıyan liderlik stili algısı ile iş yaşam kalitesi arasında anlamlı bir

$\mathrm{H}_{4}$ numaralı hipotezde $\mathrm{X}$ kuşağında dönüşümcü liderlik stili algısı ile iş yaşam kalitesi arasındaki ilişki $Y$ kuşağından farklıdır.

$\mathrm{H}_{5}$ numaralı hipotezde $\mathrm{X}$ kuşağında sürdürümcü liderlik stili algısı ile iş yaşam kalitesi arasındaki ilişki Y kuşağından farklıdır.

$\mathrm{H}_{6}$ numaralı hipotezde ise $\mathrm{X}$ kuşağında serbestlik tanıyan liderlik stili algısı ile iş yaşam kalitesi arasındaki ilişki Y kuşağından farklıdır.

Bu durumda $\mathrm{H}_{1}, \mathrm{H}_{2}, \mathrm{H}_{3}$ ve $\mathrm{H}_{5}$ numaralı hipotezler kabul edilirken, $\mathrm{H}_{4}$ ve $\mathrm{H}_{6}$ numaralı hipotezler reddedilmiştir.

Araştırma sonuçları konusu itibariyle yapılan benzeri çalışmalarla büyük ölçüde örtüşen sonuçlar ortaya koymuştur. Örnek olarak Yalçın'ın, (2014, s.152) eğitim alanında okullarda öğretmenler üzerinde yaptı̆̆ araştırmada, dönüşümcü liderlik stili ile iş yaşam kalitesi arasında anlamlı bir ilişki olduğu görülmüştür. Kamu ve özel sektörde dönüşümcü liderlik ile iş tatmini arasındaki ilişkiyi inceleyen Bozkır, $(2014$, s.80) çalışmamıza benzer şekilde dönüşümcü liderlik anlayışını benimseyen üstlerin çalışanlarının iş tatminini arttırdığını gözlemlemiştir.

Çalışmamıza benzer bir çalışma yapan Önder, (2007, s. 190) kara havacı pilotların algıladıkları liderlik stillerinin iş yaşam kalitesinin en büyük etkenlerinden olan iş doyumu üzerine yaptığ araştırmasında da dönüşümcü liderlik ile iş doyumu arasında pozitif yönde, sürdürümcü liderlik ile iş doyumu arasında benzer sonuçlar bulmuştur. Fakat serbestlik tanıyan liderlik algısı ile iş doyumu arasında ise yapılan çalışmada ters yönlü bir ilişki saptamıştır. Bu noktada araştırmacının aksine çalışmamızda serbestlik tanıyan liderlik ile iş yaşam kalitesi arasında zayıf fakat anlamlı bir ilişki bulunmuştur.

Bu çalışma, Ankara, İstanbul ve İzmir illerinde yaşayan X ve Y kuşağına mensup çalışanlarının katılımı ile cevaplandırdıkları Algılanan Liderlik Stili Anketi ve İş Yaşam Kalitesi Anketi aracılığı ile oluşturulmuştur. Anket sonucu elde edilmiş olan veriler ve verilerin analizinde kullanılan yöntemler araştırmanın genel hatlarını belirlemiştir.

Sonuç olarak çalışmamızın günümüzde gerek kamu, gerekse özel sektör tarafından giderek daha fazla üzerinde durulmaya başlanan ve sürekli geliştirilmeye açık iş yaşam kalitesi kavramı üzerinde yapılacak çalışmalar için kullanılması araştırmacılara tavsiye edilir. X kuşağı yaş aralı̆̆ının genel kabulünün 1965-1980 doğumlular olduğu, Y kuşağı yaş aralığının ise 1980-1999 arası doğanlar olarak kabul edildiği günümüzde çalışma yaşamına yeni yeni gireceğini kabul edeceğimiz Z kuşağına mensup yani 2000 ve sonrası doğumluların da araştırmaya dâhil edildiği ayrıntılı bir çalışma gerçekleştirilebilir. Ayrıca dünyanın farklı ülkelerinde görev yapan çalışanların benzeri bir ankete verdiği cevaplarla oluşturulacak bir araştırma ile de ülkeler bazında çalışanların iş yaşam kalitelerine ilişkin ayrıntılı bulgular elde edilmesini sağlayabilecektir. 


\section{Kaynaklar}

Aba, G. (2009). İş Yaşam Kalitesi ve Motivasyon İlişkisi: Sağlık Sektöründe Bir Uygulama. Yayımlanmamış Yüksek Lisans Tezi. Antalya: Akdeniz Üniversitesi, Sosyal Bilimler Enstitüsü.

Akan, D., \& Yalçın, S. (2015). Okul Yöneticilerinin Liderlik Stilleri İle Öğretmenlerin Örgütsel Bağlılıkları Arasındaki İlişkinin İncelenmesi. Eğitim ve İnsani Bilimler Dergisi, 6(11), 125.

Akdemir, A. (1998). Vizyon Yönetimi. İstanbul: Bayrak Mat. Ltd. Şti.

Argyris, C. (1976). Increasing leadership effectiveness. New York: Wiley-Interscience. p.227

Bass, B. (1990). Handbook Of Leadership: A Survey Of Theory and Research. New York: Free Press.

Başaran, A. (2006). İlköğretim Okulu Öğretmenlerinin Algıladıkları Liderlik Stilleri İle İş Doyum Düzeyleri Arasındaki İlişki. istanbul: T.C. Yeditepe Üniversitesi Sosyal Bilimler Enstitüsü .

Bennis, W. ve Nanus, B. (1985). Leaders: The strategies for taking charge. p.56

Boran, S. (2008). Sakarya Üniversitesi. Sakarya Üniversitesi Web Sitesi: http://content.lms.sabis.sakarya.edu.tr/Uploads/37528/30129/tky1hafta.pdf

Bozkır, H. S. (2014). Dönüşümcü Liderlik İle İş Tatmini Arasındaki İlişkinin İncelenmesi: Kamu ve Özel Sektör Çalışanlarına Yönelik Bir Araştırma. İstanbul: Yıldız Teknik Üniversitesi Sosyal Bilimler Enstitüsü İşletme Anabilim Dalı.

Canbolat, S. (2016). Yöneticilerin Liderlik Tarzlarına İlişkin Çalışan Algıları, Çedaş Grup Şirketleri Örneği (Çorumgaz, Sürmeligaz, Kargaz). Çorum, Yayınlanmış Yüksek Lisans Tezi: T.C. Hitit Üniversitesi Sosyal Bilimler Enstitüsü İşletme Ana Bilim Dalı.

Çelik, V. (2013). Eğitimsel Liderlik. Ankara: Pegem Akademi.

Çelik, C., \& Sünbül, Ö. (2008). Liderlik Algılamalarında Eğitim ve Cinsiyet Faktörü: Mersin İlinde Bir Alan Araştırması. Süleyman Demirel Üniversitesi İktisadi ve İdari Bilimler Fakültesi Dergisi, 13(3), 49-66.

Eğriboyun, D. (2015). Çok Faktörlü Liderlik Uygulamaları Ve İş Doyumu. İzmir: Etki Yayınları.

Erdem, M. (2010). Öğretmen Algılarına Göre Liselerde İş Yaşamı Kalitesi ve Örgütsel Bağlılıkla İlişkisi. Kurum ve Uygulamada Ĕgitim Yönetimi, 16(4), 511-536.

Erdoğan, İ. (1996). İşletme Yönetiminde Örgütsel Davranış. İstanbul: İstanbul Üniversitesi İşletme Fakültesi Yayını.

Eren, E. (2005). Örgütsel Davranış ve Yönetim Psikolojisi (Genişletilmiş 8. Baskı b.). İstanbul: Beta Basım Yayım Dağıtım.

Güney, S. (2009). Davranış Bilimleri. Ankara: Nobel Yayın Dağıtım.

Graen, G.B. (1976). Role making processes within complex organizations. Handbook of Industrial and Organizational Psychology (pp. 1201-1245). Chicago: Rand-McNally,

Judge, T., \& Piccolo, R. (2004). Transformational and Transactional Leadership: A meta-analytic test of their relative validity. Journal of Aplplied Psychology(89), 755-768.

Koçel, T. (2015). Iş̧letme Yöneticiliği. İstanbul: Beta.

Kösterelioğlu, M. (2011, Haziran). İlköğretim Okulu Öğretmenlerinin İş Yaşam Kalitesi İle İşe Yabancılaşması Arasındaki İlişki. Bolu, Yayınlanmış Doktora Tezi: T.C. Abant İzzet Baysal Üniversitesi Sosyal Bilimler Enstitüsü Eğitim Yönetimi ve Denetimi Anabilim Dalı.

Miner, J. (1992). Industrial- Organizational Psychology. Singapore: McGraw-Hill Int.

Onal, G. (1993, No: 456-689). Temel İşletmecilik Bilgisi. M.Ü Nihad Sayar Eğitim Vakfı Yayını, s. 4. 
Önder, S. (2007). Kara Havacı Pilotların İş Doyum Düzeyleri ve Algılanan Liderlik Stillerinin İş Doyum Düzeylerine Etkileri. Ankara: Gazi Üniversitesi Eğitim Bilimleri Enstitüsü.

Özcan, Y. (2006). İlköğretim Öğretmenlerinin İş Tatmini İle Yöneticileri İçin Algıladıkları Liderlik Davranışları Arasındaki İlişki Düzeyi. İstanbul, Yayınlanmış Yüksek Lisans Tezi: T.C. Yeditepe Üniversitesi Sosyal Bilimler Enstitüsü.

Özcan, E. (2011). Kişilik Bakış Açısından Örgüt Yapısı ve Işs Tatmini. istanbul: Beta.

Paşa, M. (2002). Yasam Kalitesini Yükselten Temel Unsur Olarak İşin İnsancıllaştırılması. İş-Güç endüstri Iliş̧kileri ve Insan Kaynakları Dergisi, Cilt:4 Sayı:1 http://www.isgücdergi.org.

Rob-Jan, J. (2015). The Art of Leading by Looking Ahead, Chapter 1, The Groundwork

Sabuncuoğlu, Z., \& Tüz, M. (2013). Örgütsel Davranış. Bursa: Aktüel Yayınları Alfa Akademi.

Serbest, F. (2000). " İş Yaşamı Niteliği (QWL)". Verimlilik Dergisi(2), 27,40.

Tengilimoğlu, D. (2005). Kamu ve Özel Sektör Örgütlerinde Liderlik Davranışı Özelliklerinin Belirlenmesine Yönelik Bir Alan Çalışması. Elektronik Sosyal Bilimler Dergisi C.4 S. 14 , 1-16.

Tuncer, M., \& Yeşiltaş, M. (2013). Çalışma Yaşam Kalitesinin Otel İşletmesi Çalışanları Üzerindeki Etkileri. İşletme Araştırmaları Dergisi, 57-78.

Tütüncü, Ö. (2008). Sosyal Sorumluluk Standardı İle İş Yaşamı Kalitesi Arasındaki İlişki. Dokuz Eylül Üniversitesi Sosyal Bilimler Enstitüsü Dergisi, 10(2), 178.

Yalçın, S. (2014). Öğretmenlerin Algılarına Göre Okul Yöneticilerinin Liderlik Stilleri İle Öğretmenlerin İş Yaşam Kalitesi Ve Örgtütsel Bağlılık Düzeyleri Arasındaki İlişkinin İncelenmesi. Erzurum, Yayınlanmış Doktora Tezi: Atatürk Üniversitesi Eğitim Bilimleri Enstitüsü .

Yıldız, S. M. (2013). Spor ve Fiziksel Etkinlik İşletmelerinde İş Yaşam Kalitesinin Çalışanların İşten Ayrılma Niyetine Etkisi. Ege Akademik Bakış, 13(3), 317-324. 